\title{
Interpretacja pokutna Janowego opisu obmycia stóp uczniom przez Jezusa. Część 1: Interpretacje sakramentalne na tle współczesnych wyjaśnień J 13,1-20
}

\author{
Penitential Interpretation of the Johannine Foot-washing. \\ Part 1: Sacramental Interpretations against the Background \\ of Current Explanations of John 13:1-20
}

\author{
KS. ADAM KUBIŚ \\ Instytut Nauk Biblijnych, Katolicki Uniwersytet Lubelski Jana Pawła II \\ e-mail: adamkubis@kul.pl \\ ORCID: 0000-0003-4961-2254
}

\begin{abstract}
Summary: The article deals with the Johannine narrative on the foot-washing, giving a critical review of the current scholarship on the interpretation of Jesus' gesture (Part 1) and adding a new argument in favor of a penitential reading of the pericope (Part 2). The first part of the study presents status quaestionis, summarizing various interpretations, distilled into three categories: (1) naturalistic or socio-cultural, (2) symbolic, and (3) sacramental. This initial survey starts with a review of all possible ancient cultural contexts, both pagan and Jewish, in which foot-washing occurred, followed by various possible readings of the pericope based on these backgrounds; our analysis suggests that the purely naturalistic explanations do not resolve satisfactorily all the complexities of the text. Next, at least fifteen arguments are enumerated in favor of a symbolic interpretation, with a short survey of noteworthy examples of this approach. Then, various sacramental readings are presented, with a special focus on the baptismal explanation, which indeed has held the most prominent position among the sacramental interpretations within the historical exegesis of the text.
\end{abstract}

KEYWORDS: foot-washing, John 13:1-20, baptism, penance, sin

\section{Wstęp: Postawienie problemu, cel i struktura studium}

\footnotetext{
pośród Ewangelii kanonicznych jedynie księga Janowa opisuje Jezusa obmy-

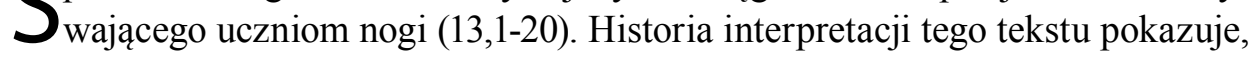
iż główny problem, jaki powstaje w czasie jego lektury, to brak jednoznacznego znaczenia gestu Jezusa. Jeszcze kilkadziesiąt lat temu nie istniał konsensus w kwestii wymowy tego gestu. Niejasność interpretacyjna doprowadziła nawet do pominięcia tego tekstu przez niektóre studia dotyczące wspólnoty Janowej,
} 
stojącej za powstaniem Ewangelii Jana ${ }^{1}$. Również spotykane w przeszłości próby podważania historyczności obmycia nóg współcześnie zostały ocenione jako nieprzekonujące ${ }^{2}$ i niedotykające istoty problemu, jaką jest interpretacja opisanego wydarzenia ${ }^{3}$. Obecnie opinio communis opowiada się za symbolicznym znaczeniem czynności Jezusa, odsuwając na drugi plan wyjaśnienia socjologiczno-kulturowe oraz sakramentalne. Niniejszy artykuł stawia sobie za cel prezentację interpretacji pokutnej gestu Jezusa wraz z dodaniem kolejnego argumentu za możliwością pokutnego rozumienia $J$ 13,1-20 - tym razem zaczerpniętego $\mathrm{z}$ antropologii kulturowej. Warto podkreślić, iż interpretacja pokutna J 13,1-20 jest współcześnie marginalizowana. Opublikowane w $1991 \mathrm{r}$. monograficzne studium tekstu J 13,1-20 dokonane przez Johna Christophera Thomasa wskazało właśnie pokutne znaczenie oczyszczenia z grzechów jako właściwe wytłumaczenie gestu umycia nóg ${ }^{4}$. Głos ten nie przebił się jednak do powszechnej świadomości interpretatorów, nie znajdując uznania u autorów komentarzy do czwartej Ewangelii ${ }^{5}$. Warto jednak pamiętać, iż interpretacja pokutna umycia nóg uczniom przez Jezusa była znana i ceniona wśród komentatorów starożytnych i średniowiecznych. Wobec powyższego prezentacja

1 R.A. Culpepper, The Johannine School. An Evaluation of the Johannine-School Hypothesis Based on an Investigation of the Nature of Ancient Schools (SBL Dissertation Series 26; Missoula, MO: Scholars Press 1975); O. Cullmann, The Johannine Circle. Its Place in Judaism, among the Disciple of Jesus and in Early Christianity. A Study in the Origin of the Gospel of John (London: Westminster 1976).

2 Na temat historyczności tego gestu zob. R. Bauckham, „Did Jesus Wash His Disciples’ Feet?”, Authenticating the Activities of Jesus (red. B.D. Chilton - C.A. Evans) (New Testament Tools and Studies 28/2; Leiden - Boston - Köln: Brill 1999) 411-429; J. Clark-Soles, „John 13: Of Footwashing and History", John, Jesus, and History. Volume 2: Aspects of Historicity in the Fourth Gospel (red. P.N. Anderson - F. Just - T. Thatcher) (Early Christianity and Its Literature 2; Atlanta, GA: Society of Biblical Literature 2009) 255-269.

3 Amerykańska egzegetka S.M. Schneiders, „The Foot Washing (John 13:1-20): An Experiment in Hermeneutics", $C B Q 43$ (1981) 79, odwołując się współczesnych teorii hermeneutycznych H.-G. Gadamera oraz P. Ricoeura, stwierdza: „The primary question posed to the interpreter by the episode of the foot washing in John is not whether Jesus actually washed his disciples' feet or actually spoke the following discourse, but rather what interpretation of life and relationships does it present, is that interpretation true, and if so what are the implications for the interpreter's own self-understanding".

4 J.C. Thomas, Footwashing in John 13 and the Johannine Community (JSNTSS 61; Sheffield: JSOT Press 1991). W zakończeniu swej rozprawy (s. 188) autor ten dokonuje wiele mówiącej oceny współczesnych komentarzy w odniesieniu do wyboru interpretacji tekstu J 13,1-20: „This finding [Thomas's book] reveals that, at the very least, scholars have not taken a major interpretative option seriously enough [i.e. penitential interpretation], often mentioning a possible penitential interpretation of Jn 13.1-20 in a single sentence".

5 Wcześniejszym istotnym głosem za pokutną interpretacją $\mathrm{J}$ 13,1-20 była praca P. Grelota, „L'interprétation pénitentielle du lavement des pieds: examen critique”, L'homme devant Dieu. Mélanges offerts au Père Henri de Lubac. Exégèse et patristique (Théologie 56; Paris: Aubier 1963) 75-91. Również i ona nie znalazła szerszego odzewu w późniejszych komentarzach do czwartej Ewangelii. 
w poniższym artykule kolejnego argumentu za takim rozumieniem tego gestu jest próbą przywrócenia tej interpretacji właściwego jej miejsca we współczesnej egzegezie czwartej Ewangelii.

Niniejsze studium podzielone zostało na dwie części. Zasadnicze analizy, poświęcone interpretacji pokutnej gestu Jezusa w świetle antropologii kulturowej, znajdują się w części drugiej artykułu. Część pierwsza natomiast stanowi użyteczny zarys dotychczasowych prób rozumienia badanej perykopy Janowej, który nie pretenduje jednak do miana ujęcia wyczerpującego, a więc ujmującego wszystkie możliwości. W 1967 r. G. Richter zliczył jedenaście interpretacji, jakie do tego czasu powstały ${ }^{6}$. Dziś jest ich już znacznie więcej. Prezentacja status quaestionis, dając syntetyczny przegląd głównych prób wyjaśnienia tego gestu, pozwoli na dokładne umiejscowienie interpretacji pokutnej na tle szerokiego spectrum innych rozwiązań. Należy jednak podkreślić, iż celem tego wprowadzenia jest nie tyle opisowa prezentacja swoistego status quaestionis, ile raczej krytyczna ocena, a zatem ukazanie braków i niewystarczalności wykładni dosłownych oraz sakramentalnych innych niż pokutna. Braki interpretacji dosłownych uzasadniają konieczność zaistnienia wyjaśnień ponaddosłownych (symbolicznych i sakramentalnych). Podobne zjawisko zachodzi w przypadku sakramentalnego rozumienia tekstu, gdzie niewystarczalność interpretacji chrzcielnej czy eucharystycznej otwiera drogę dla poszukiwań innych rozwiązań. W efekcie, wyjaśnienie symboliczne i sakramentalne, a konkretnie odwołujące się do symboliki sakramentu pokuty, wyjaśniając tekst w sposób najbardziej kompleksowy, okazuje się najbardziej przekonujące. Krytyczna ocena różnych wyjaśnień, wskazująca ich zalety oraz braki, pomaga zatem w uchwyceniu genezy interpretacji pokutnej J 13,1-20.

Wielorakie próby wyjaśnienia znaczenia gestu umycia nóg uczniom przez Jezusa, przedmiot zainteresowania pierwszej części artykułu, można usystematyzować poprzez wyróżnienie dwóch zasadniczych kategorii interpretacji: (1) dosłowne czy też socjologiczno-kulturowe lub naturalistyczne oraz (2) ponaddosłowne lub symboliczne. Dla jasności prezentacji obecnego stanu badań, w niniejszym studium wyróżniono jeszcze trzecią grupę, a mianowicie interpretacje sakramentalne (3). W swej istocie przynależą one jednak do wyjaśnień ponaddosłownych ${ }^{7}$.

6 G. Richter, Die Fusswaschung im Johannesevangelium. Geschichte ihrer Deutung (Biblische Untersuchungen 1; Regensburg: Verlag Friedrich Pustet 1967). Taką samą liczbę, w tym samym roku, podał w swojej dysertacji doktorskiej W. Lohse, Die Fusswaschung (Joh 13.1-20). Eine Geschichte ihrer Deutung (Friedrich-Alexander-Universität zu Erlangen-Nürnberg 1967).

7 Najbardziej obszerną prezentację status quaestonis zawiera praca: J.C. Thomas, Footwashing in John 13 and the Johannine Community (JSNTSS 61; Sheffield: JSOT Press 1991) 26-60. Opracowanie J.C. Thomasa w części opiera się na danych zebranych i opublikowanych w $1972 \mathrm{r}$. w B. Kötting, „Fusswaschung”, RAC VIII, 744-461. Praca J.C. Thomasa uzupełnia prezentację 


\section{Interpretacje socjologiczno-kulturowe}

Interpretacje socjologiczno-kulturowe szukają paraleli Jezusowego gestu umycia nóg w kulturze żydowskiej oraz grecko-rzymskiej. Objaśnienia te możemy zatem nazwać dosłownymi, gdyż szukają sensu Jezusowego gestu, który będzie historycznie wiarygodny oraz zrozumiały w kontekście kultury przynależnej Jezusowi i Jego uczniom oraz autorom i słuchaczom czwartej Ewangelii. Jak się okaże, tekst Janowy wymyka się jednak rozumieniu dosłownemu i zaprasza do poszukiwania sensu wykraczającego poza dosłowność.

\section{1. Żydowskie i grecko-rzymskie tło kulturowe}

Komentatorzy Janowego opisu obmycia uczniom nóg przez Jezusa wyróżniają z zasady dwa kulturowe obszary, w których praktykowano obmycie nóg i które mogą mieć wpływ - ze względów geograficznych i chronologicznych - na zrozumienie gestu Jezusa. Mowa o kulturze judaistycznej okresu Drugiej Świątyni oraz kulturze grecko-rzymskiej przełomu er.

W obszarze żydowskiem obmycia nóg praktykowano w kontekście kultycznym. Otóż, (1) kapłani robili to przed wejściem do miejsca sprawowania liturgii (Wj 30,19-21; 40,31). (2) W czasach Jezusa robiły to także wszystkie pozostałe osoby przed wejściem do świątyni (Filon, Q. Exod. 2,1,2; m. Ber 9,6) ${ }^{8}$. (3) W tym

stanu badań znajdującą się w wyżej wzmiankowanych pracach doktorskich G. Richtera i W. Lohse z 1967 r. J.C. Thomas wyróżnia siedem wiodących interpretacji: (1) znak pokory, (2) Eucharystia, (3) chrzest, (4) przebaczenie grzechów i/lub oczyszczenie, (5) sakrament różny od chrztu i Eucharystii, (6) znak soteriologiczny, (7) wyraz polemiki. Wybranych autorów publikujących w latach 1991-2014, a zatem po ukazaniu się pracy J.C. Thomasa, omawia B. Mathew, The Johannine Footwashing as the Sign of Perfect Love. An Exegetical Study of John 13:1-20 (WUNT 2/464; Tübingen: Mohr Siebeck 2018) 9-32. Autor ten dzieli współczesne interpretacje na dwie kategorie: niesakramentalne i sakramentalne. W języku polskim syntetyczne omówienie stanu badań prezentuje S. Mędala, Ewangelia wedtug świętego Jana. Rozdziaty 13-21. Wstęp, przekład $z$ oryginału, komentarz (NKB.NT 4/2; Częstochowa: Edycja Świętego Pawła 2010) 42-50 oraz 64-69, który dzieli interpretacje na cztery kategorie: (1) przykład pokory i uniżenia, (2) znak zbawczego dzieła Jezusa, (3) znak powierzenia uczniom szczególnej misji, (4) odniesienia do sakramentów.

8 Chrześcijański dokument z IV w., Pap. Oxyrh. 840, mówi o wizycie Jezusa w Świątyni Jerozolimskiej i wystąpieniu arcykapłana Lewiego ze stronnictwa faryzeuszy, który twierdzi, iż Jezus nie ma prawa chodzić po posadzce świątyni i patrzeć na święte naczynia „ponieważ sam się nie wykąpał i jego uczniowie nie umyli nóg”. Dokładne omówienie papirusu J. Jeremias, „Der Zusammenstoß Jesus mit dem pharisäischen Oberpriester auf dem Tempelplatz: Zu Pap. Ox. V, 840”, CNT 11 (1947) 97-108 oraz F. Bovon, „Fragment Oxyrhynchus 840, Fragment of a Lost Gospel, Witness of an Early Christian Controversy Over Purity", JBL 119 (2000) 705728. Zob. także M.J. Kruger, The Gospel of Savior. An Analysis of P.Oxy V 840 and Its Place in the Gospel Traditions of Early Christianity (Texts and Editions for New Testament Study 1; Leiden: Brill 2005), zwłaszcza s. 179-182 traktujące o związku z J 13,10. 
samym okresie praktykowano ten zwyczaj przed rytualną wieczerzą paschalną (Filon, De spec. leg. II, 148) ${ }^{9}$. Prócz powyższego kontekstu kultycznego obmycia nóg w starożytnym judaizmie stosowano także z racji (4) higieny osobistej (2 Sm 11,8-11; 19,24; Pnp 5,3) oraz jako (5) znak gościnności w stosunku do przybysza na początku jego wizyty. W tym przypadku obmycie nóg $\mathrm{z}$ reguły poprzedzało posiłek (Rdz 18,4; 19,2; 24,32; 43,24; Sdz 19,21; Łk 7,44; Testament Abrahama 3; Józef $i$ Asenet 7,1). Warto zauważyć, iż w każdym z powyższych tekstów tłumaczenie LXX używa czasownika ví $\tau \omega$, który występuje także w narracji Janowej (13,5.6.8bis.10.12.14bis). W pewnych tekstach biblijnych i pozabiblijnych obmycie stóp jest również (6) metaforą poddaństwa, niewolnictwa, posługi (1 Sm $25,41 ;$ Ps 60,$8 ; 108,9)$. Może być także (7) znakiem najwyższej miłości (Józef $i$ Asenet 13,12; 20,1-5; Łk 7,38.47; J 12,3).

Nie ulega wątpliwości, iż w świecie żydowskim mycie nóg należało do obowiązków niewolników. W przypadku ich braku obmycia dokonywali sami goście, nigdy jednak nie robił tego gospodarz ${ }^{10}$. Warto jednak podkreślić, iż w źródłach rabinackich niewolnik mężczyzna pochodzenia żydowskiego jest zwolniony z obowiązku mycia stóp swoim właścicielom; jednocześnie wskazuje się na niewolnice kobiety jako przeznaczone do tej posługi. Rabini widzieli także mycie stóp, obok przygotowania posiłków i posłania, jako jeden z obowiązków żon w stosunku do mężów. Czynność mycia nóg mogły także wykonywać - choć nie było to nakazane - dzieci w stosunku do rodziców oraz oddani uczniowie w stosunku do ich rabinackich nauczycieli ${ }^{11}$.

9 Szerzej R. Kieffer, „L'arrière-fond juif du lavement des pieds”, RB 105 (1998) 546-555. Stwierdzenie istnienia zwyczaju obmyć przed ucztą paschalną w związku z J 13,10 zawarte jest w szwedzkim tłumaczeniu z 1981 r. dzieła J. Jeremiasa, Die Abendmahlsworte Jesu (Göttingen: Vandenhoeck \& Ruprecht $\left.{ }^{3} 1960\right) 43$ oraz 76, który w tekście niemieckim wskazywał na możliwość istnienia kąpieli rytualnej mającej miejsce przed ucztą paschalną i mającej swe źródło w kapłańskich regulacjach dotyczących czystości rytualnej (zob. Lb 19,19). Zwyczaj rytualnych obmyć związanych ze spożywaniem wieczerzy paschalnej potwierdzony jest w istocie przez Filona, De specialibus legibus II, 148.

10 Jedynym wyjątkiem w literaturze żydowskiej jest Testament Abrahama $(3,6-9)$, według którego Abraham umył nogi trzem nieznajomym gościom (por. Rdz 18,1-8). Apokryf zakłada jednak wyższy status społeczny przybyłych gości. Co ciekawe, recenzja B tego apokryfu dodaje, iż Abraham zawsze mył nogi swoim wszystkim gościom. Z reguły uznaje się tę wersję tekstu apokryfu jako chrześcijański dodatek, odzwierciedlający praktykę chrześcijańską w której gospodarz mył nogi gościom. Orygenes (Hom. in Gen. 4,2) wskazuje Abrahama jako przykład dla chrześcijan w umywaniu nóg przybyszom. Nie uwzględniając nawet recenzji B jako naznaczonej interpolacjami chrześcijańskimi, Abraham jawi się w świetle drugiej wersji tego apokryfu jako wyjątkowo pokorna postać traktująca wszystkich przybyszów jako społecznie wyżej postawionych. W tym wypadku wyjątek postawy Abrahama potwierdza regułę, według której osoba o wyższej pozycji społecznej nie dokonywała obmyć nóg osobie stojącej na niższym szczeblu drabiny społecznej. Zob. Bauckham, „Did Jesus Wash His Disciples' Feet?”, 413-414.

11 m. Qidd. 1,3; b. Ketub. 61a; b. Qidd. 22b; t. Qidd. 1,11; Mekhilta R. Ishmael Wj 21,2 (krytykowana jest tutaj możliwość posługi matki w stosunku do syna, będącego rabinem); 'Abot R. Nat 16; Sifra Kpł 25,39; Sifra Pwt 33,24. 
W świecie grecko-rzymskim stosowanie i znaczenie gestu obmycia nóg było podobne do jego użycia i rozumienia w starożytnej kulturze żydowskiej. Obmycie to było zatem związane z (1) kultem (czynność ta poprzedzała wejście do miejsca świętego) ${ }^{12}$ oraz (2) higieną ${ }^{13}$. Gest ten był także (3) znakiem powitania i pozdrowienia (nieznajomy zmieniał swój status na gościa) ${ }^{14}$ oraz (4) elementem przygotowania do posiłku ${ }^{15}$. Co ciekawe, wskazuje się kilka paraleli tematycznych i leksykalnych między opisem umycia nóg przed posiłkiem, jaki znajduje się w Vita Aesopi 61 (I-II w. po Chr.), a opisem z J 13,1-20 ${ }^{16}$. Nie ulega również wątpliwości, iż w kulturze grecko-rzymskiej czynność mycia stóp wykonywana była przez niewolników, zarówno kobiety, jak i mężczyzn, i była znakiem niewolnictwa ${ }^{17}$.

\subsection{Dosłowne propozycje interpretacyjne}

W przypadku opisu Janowego widoczne są dwie niezgodności z ówczesnymi zwyczajami żydowskimi i grecko-rzymskimi. Po pierwsze, Jezus czyni to $\mathrm{w}$ trakcie posiłku, podczas gdy regułą było obmycie poprzedzające posiłek (w czasie posiłku dopuszczalne było jedynie umycie rąk $\mathrm{k}^{18}$ ). Po drugie, obmycia nie dokonuje niewolnik, sługa czy uczeń, ale Jezus, nauczyciel, pełniący funkcję gospodarza. Zasadność mówienia o odejściu od normy w pierwszym przypadku jest niekiedy kwestionowana, gdyż gramatyka grecka pozwala na rozumienie

12 Homer, Iliada 16,235; Strabon, Geografia 7,328.

13 Lucjan, Demonax 4; Juwenalis, Satyry 3,271-277; Apulejusz, Apologia 8.

14 Homer, Odysea 19,308-319; Atenajos, Deipnosophistae 13,583-584. Zob. B.J. Malina, „The Received View and What It Cannot Do: III John and Hospitality", Semeia 35 (1986) 171-189, zwłaszcza 183: „Frequently the ritual of footwashing marks the movement from stranger to guest".

15 Często dokonywano kąpieli całego ciała przed ucztą (Ksenofont, Symp. 7; Lucjan, Asin. 3), a w momencie przybycia na samą ucztę niewolnik gospodarza obmywał ręce i/lub nogi oraz stosował namaszczenie (Platon, Symp. 175A; Plutarch, Sept. Sap. Conv. 3; Atenajos, Deipnosophistae 4.169a).

16 J. Sammer, „Why Did Jesus Wash His Disciples Feet?”, Aeon 3/4 (1993) 21-32; A. Destro M. Pesce, „La lavanda dei piedi di Gv 13,1-20, il Romanzo di Esopo e i Saturnalia di Macrobio”, Bib. 80/2 (1999) 240-249, zwłaszcza 242-243.

17 Oczywiście literatura grecko-rzymska zna wyjątki, gdy człowiek wolny umywa nogi drugiej osobie, mając również status człowieka wolnego. Wyjątki te potwierdzają jednak regułę, gdyż autorzy każdy taki przypadek opatrywali wyjaśnieniem. Nawet jednak w tych przykładach wolna osoba o wyższym statusie społecznym nigdy nie myła nóg osobie wolnej o niższym statusie. Zob. Arystofanes, Vespae 605-611; Vita Aesopi 61; Meleager, Anthol. Pal. 12,68; Plutarch, Moralia 12,249d; Plutarch, Pomp. 73.6-7.

18 Atenajos, Deipn. 2.60a; 9.408b-409a. Zaburzenie zwyczajowej sekwencji, wpierw obmycie/ namaszczenie potem posiłek, potępione jest w Petroniusz, Sat. 70, gdzie namaszczenie ma miejsce w czasie posiłku. 
zwrotu $\delta \varepsilon i ́ \pi v o v ~ \gamma ı v o \mu \varepsilon ́ v o v(13,2)$ jako ogólnego stwierdzenia oznaczającego czas wieczerzy (,gdy nadszedł czas wieczerzy”) czy też zaistnienie wieczerzy (,z okazji wieczerzy”) ${ }^{19}$. Jednakże drugie odejście od zwyczajowych reguł stało się podstawą do poszukiwania naturalistycznych („dosłownych”) wyjaśnień gestu Jezusa na gruncie kultury starożytnej.

\section{Saturnalia a inwersja ról i równość statusu}

Zdaniem A. Destro i M. Pescego powyższa niezgodność ze starożytnymi normami sugeruje, że tekst mówi o radykalnej inwersji ról inicjującej idealistyczny zamysł (progetto di utopia) stworzenia wspólnoty, w której będzie naśladowana postawa Jezusa - sługi/niewolnika. W tej wspólnocie uczniów Jezusa mają zaniknąć wszelkie różnice odnośnie do statusu społecznego jej członków, gdyż ma to być społeczność przyjaciół (società di amici) $)^{20}$.

Równość statusu we wspólnocie uczniów może mieć również swoje odniesienie do starożytnej kultury grecko-rzymskiej, w której celebrowano odwrócenie ról w czasie świąt zwanych Saturnaliami ${ }^{21}$. Na wspomnianą inwersję ról (obecną w Saturnaliach), jako istotę przesłania tekstu Janowego, kładą nacisk w swych publikacjach J. Sammer, A. Destro i M. Pesce. Celem Saturnaliów

19 R. Bultmann, The Gospel of John. A Commentary (Philadelphia: The Westminster Press 1971) 465, przyp. 2: „on the occasion of a meal”. M.L. Coloe, „Welcome into the Household of God: The Foot Washing in John 13", CBQ 66 (2004) 406-407. Próbę wykazania, iż Jezusowa czynność umycia nóg miała miejsce na początku wieczerzy paschalnej, podejmuje także A. Peloni, „The Daily Washing of the Once Bathed (St. John xiii. 10)", The Exp. $2 / 4$ (1882) 146-156, zwłaszcza

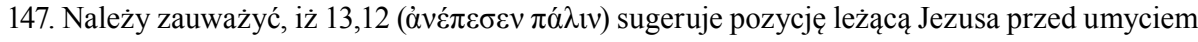
nóg, a zatem rozpoczęcie uczty przed umyciem nóg.

20 A. Destro - M. Pesce, „La lavanda dei piedi nel Vangelo di Giovanni: un rito di inversione”, Atti del VI Simposio di Efeso su S. Giovanni apostolo (red. L. Padovese) (Turchia: La Chiesa e la Sua Storia 11; Roma: Istituto Francescano di Spiritualità - Pontificio Ateneo Antoniano 1996) 9-27; A. Destro - M. Pesce, „L'iniziazione dei discepoli nel Vangelo di Giovanni: La lavanda dei piedi come rito di ingresso al discepolato", Iniziazione cirstiana degli adulti oggi. Atti della XXVI settimana di studio dell'Associazione Professori di Liturgia. Seiano di Vico Equense (NA). 21 agosto - 5 settembre 1997 (B.E.L. Subsidia 99; Roma: C.L.V.-Edizioni Liturgiche 1998) 47-74; M. Pesce, „Il lavaggio dei piedi (Gv 13,1-20)”, Opera giovannea (red. G. Ghiberti) (Logos. Corso di Studi Biblici 7; Torino: Elledici 2002) 233-250. Inwersja ról jest także głównym przesłaniem J 13,1-20 w opinii M.A. Matsona, „To Serve as Slave. Footwashing as Paradigmatic Status Reversal”, One in Christ Jesus. Essays on Early Christianity and „All That Jazz", in Honor of S. Scott Bartchy (red. D.L. Matson - K.C. Richardson) (Eugene, OR: Pickwick Publications 2014) 113-131.

21 Odwrócenie zwyczajowej roli osób, gospodarz-niewolnik, następowało w okresie cesarstwa rzymskiego jedynie w czasie obchodów rzymskich Saturnaliów czy greckich Kronia. Wówczas to niewolnicy w szatach swoich panów zasiadali przy stołach swych właścicieli, a gospodarz (właściciel niewolników) lub jego dzieci posługiwali przy posiłku. Zob. Kasjusz Dion, Hist. Rom. 60.19; Seneka, Ep. 47.14; Atenajos, Deipn. 14.639b; Lucjan, Sat. 17; Makrobiusz, Sat. 1.7-11. 
było jednak $\mathrm{w}$ istocie potwierdzenie istniejącego status quo poprzez pokazanie absurdu świata o odwróconych zasadach współżycia społecznego ${ }^{22}$. Odwołując się zatem do powyższego celu Saturnaliów jako kontekstu interpretacyjnego tekstu Janowego, w czynności Jezusa nie musiałoby chodzić o odwrócenie ról, ale o pokazanie i wzmocnienie niezmiennych i różnych funkcji Jezusa i Jego uczniów. W świetle przesłania Ewangelii Janowej, którym jest kreowanie przez Jezusa nowej rodziny (Jezus i uczniowie są braćmi, zob. 20,17) oraz wspólnoty przyjaciół (Jezus i uczniowie są przyjaciółmi, zob. 15,15), powyższe wyjaśnienie wydaje się jednak niewłaściwe.

W naszym przekonaniu bardziej stosownym kluczem interpretacyjnym tekstu Janowego jest historyczny motyw świętowania rzymskich Saturnaliów. Było nim wspominanie równości i wolności, jaką cieszyli się wszyscy ludzie w czasach panowania króla Saturna, legendarnego władcy Kapitolu, Lacjum i całej Italii ${ }^{23}$.

Równość. Zdaniem Makrobiusza (Sat. 1,7,36-37) zanim święto pojawiło się w Rzymie, było już wcześniej obchodzone w Grecji, gdzie również w czasie celebracji następowało zrównanie statusu społecznego niewolników z ludźmi wolny$\mathrm{mi}^{24}$. Idea równości jest jak najbardziej obecna w czwartej Ewangelii, gdyż Jezus kreuje wspólnotę braci i przyjaciół, w której sam Jezus jest bratem i przyjacielem swoim uczniów. Poprzez ryt umycia nóg Jezus kreowałby zatem nie tylko wspólnotę braci i przyjaciół, ale także wspólnotę sług, w której On także jest sługą.

Wolność. Makrobiusz (Sat. 1,7,26) podkreśla także, iż w czasie Saturnaliów niewolnicy cieszyli się pełną wolnością (tota servis licentia permittitur). Idea wolności jest również obecna w czwartej Ewangelii (zob. 8,32-36). W świetle J 8,32-36, gdzie pojawia się kontrast między wolnością syna i jej brakiem w przypadku niewolnika, wolność przynoszona przez Jezusa (Syna) jest w istocie synonimem zbawienia i życia wiecznego. W Janowym rozumieniu wolność jest usynowieniem. Każdy z uczniów może się zatem cieszyć statusem syna (córki) w domu Ojca i być rzeczywiście wolnym ${ }^{25}$.

22 Zob. H.S. Versnel, „Saturnus and the Saturnalia”, Inconsistencies in Greek and Roman Religion. II. Transition and Reversal in Myth and Ritual (Studies in Greek and Roman Religion 6; Leiden: Brill 1993) 115-117: „The established order is confirmed by the absurdity of the world turned topsy-turvy".

23 Versnel, „Saturnus and the Saturnalia”, 138-139. Makrobiusz (Sat. 1,8,26) stwierdza wprost, iż w czasie panowania Saturna nie było jeszcze niewolnictwa: quod nondum quisquam servitio vel libertate discriminabatur.

24 Makrobiusz (Sat. 1,7,36-37; 1,10,22), odwołując się do świadectwa Lucio Flaccio (II/I w. przed Chr.) oraz Attydy, dzieła Filochorosa z Aten (IV-III w. przed Chr.), stwierdza, iż w Grecji świętowano Kronie zarówno w miastach, jak i wioskach, poprzez spożywanie wspólnego radosnego posiłku, w czasie którego ludzie wolni posługiwali swoim niewolnikom. Zwyczaj ten miał, zdaniem Makrobiusza, zostać przeniesiony do Rzymu, gdzie w czasie Saturnaliów niewolnicy zasiadali do stołu ze swymi panami.

25 Więcej zob. R. Kempiak, „«Poznacie prawdę, a prawda was wyzwoli» (J 8,32). Wyzwolenie wolność w ujęciu Janowym”, Scriptura Sacra 10 (2006) 187-214; A. Kubiś, „Poznacie prawdę 


\section{Pokorny sługa}

Gdy Jezus wykonuje czynność przynależną niewolnikom, swoiste odwrócenie ról, odczytywane jest to nie tylko jako znak demonstrujący pokorę Jezusa, ale przede wszystkim jako gest odsłaniający Jego prawdziwą tożsamość jako sługę/niewolnika. Temat pokory nie jest explicite wzmiankowany w perykopie,

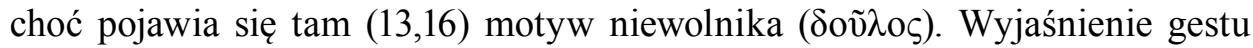
Jezusa, jako znaku Jego pokornej służby, ale i przykładu (i் naśladowania przez równych sobie uczniów, było preferowane w starożytności przez Jana Chryzostoma, Teodora z Mopsuesti czy Cyryla Aleksandryjskiego ${ }^{26}$. Współcześnie C.K. Barrett posunął się nawet do twierdzenia, iż cała narracja jest Janową konstrukcją mającą ukazać, jak Jezus w realnym życiu realizował słowa z Łk 22,27: „Któż bowiem jest większy? Ten, kto siedzi za stołem, czy ten, kto służy? Czyż nie ten, kto siedzi za stołem? Otóż Ja jestem pośród was jako ten, kto służy" ${ }^{27}$. Interpretacja ta jest jedną z najpopularniejszych wśród egzegetów, ze względu na swą oczywistość wynikającą z (1) zakorzenienia w tle kulturowym czasów Jezusa oraz (2) kontekstu chrystologicznego NT, w którym Jezus przedstawiony jest jako sługa (zob. Flp 2,6-11) ${ }^{28}$.

\section{Przyjaciel i sługa}

Propozycja Sandry Schneiders łączy wspomnianą wyżej kategorię przyjaźni (niezwykle mocno obecną w kulturze starożytnej i opartej na zasadzie równości statusu) z powyższą kategorią służby (odwołującą się do starożytnej koncepcji niewolnictwa). Amerykańska egzegetka wyróżniła trzy modele służby: (1) posługujący czyni posługę ze względu na władzę, jaką ma nad nim przyjmujący posługę (np. relacja niewolnika do właściciela niewolnika; w kulturach patriarchalnych relacja kobiety do mężczyzny); (2) posługujący wykonuje posługę,

i prawda was wyzwoli. Związek między Janowymi koncepcjami prawdy i wolności w świetle J 8,31-36", Prawda was wyzwoli (Scripturae Lumen. Biblia i Jej Oddziaływanie 4; Tarnów: Biblos 2012) 59-85.

26 Jan Chryzostom, In Joannem homiliae 70-71 (PG 59,381-396); Teodor z Mopsuesti, In Joh., fragm. 112-113 (tekst syryjski: CSCO 115; łaciński: CSCO 116,118-120); Cyryl Aleksandryjski, In Joannem 9 (PG 74,118); Hom. 10 (PG 77,1026D). Obecne jest także u Augustyna, Tractatus in Johannem 55,7 (PL 35,1738).

27 C.K. Barrett, The Gospel according to St John. An Introduction with Commentary and Notes on the Greek Text (London: SPCK ${ }^{2}$ 1978) 363. Podobieństwo między Łk 22,27 a J 13,1-20 zauważył już Orygenes.

28 J.-M. Lagrange, Évangile selon Saint Jean (Études Biblique; Paris: Gabalda 1925. ${ }^{5} 1936$ ) 354355; J.H. Bernard, A Critical and Exegetical Commentary on the Gospel According to St. John (ICC; Edinburgh: T\&T Clark 1928) II, 464; P. Fiebig, „Die Fusswaschung”, Angelos 3 (1930) 126-128; F.-M. Braun, „Le levement des pieds et la réponse de Jésus à saint Pierre”, $R B 44$ (1935) 22-33; J. Michl, „Der Sinn der Fusswaschung”, Bib. 40 (1959) 697-708. 
ponieważ ma możliwość zaradzić potrzebie, którą zauważa u przyjmującego posługę (np. matka w stosunku do swego dziecka; wyspecjalizowany profesjonalista w stosunku do niedoświadczonej osoby). Powyższe dwa modele bazują na nierówności obu stron. Ostatni model (3) funkcjonuje między przyjaciółmi. Przyjaźń zakłada równość osób. Dobro jednego przyjaciela jest w istocie dobrem drugiego. Dobro wyświadczone otrzymującemu posługę buduje także udzielającego posługi. Posługa Jezusa miała zatem na celu usunięcie nierówności w dwóch wymiarach: (a) między nim a uczniami oraz (b) pomiędzy samymi uczniami. Gest Jezusa potwierdzał status Jezusa jako przyjaciela (oddającego swe życie za przyjaciół) oraz status uczniów jako przyjaciół, równych sobie nawzajem. Bunt Piotra można zatem odczytać jako sprzeciw przeciwko (a) zrównaniu się Jezusa z Piotrem w nowej godności przyjaciół oraz (b) odebraniu Piotrowi uprzywilejowanej pozycji wśród uczniów. Piotr nie zgadza się na ofiarę z życia Jezusa, która implikuje powstanie nowego porządku relacji międzyludzkich; tym samym sprzeciwia się powstaniu nowej egalitarnej wspólnoty przyjació ${ }^{29}$.

\section{Znak miłości}

Jak wskazano powyżej, w kontekście żydowskim i nowotestamentowym umycie nóg widziane jest jako znak najwyższej miłości (zob. Józef i Asenet 13,12; 20,1-5; Łk 7,38.47; J 12,3). Kontekst Janowego obmycia nóg mówi wprost o miłości jako

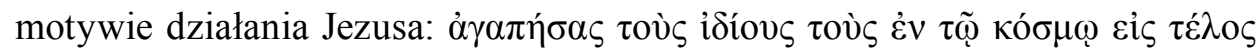

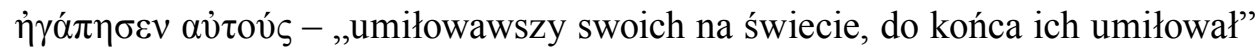
$(13,1)$. Miłość Jezusa „do końca” odnosi się zarówno do oddania Jego życia $(3,16)$, jak i do samego gestu umycia nóg. Czynność ta, powtarzana przez uczniów, ma wyrażać ich wzajemną miłość, wzorowaną na miłości samego Jezusa; miłość gotową do oddania życia $(13,34 ; 15,3)^{30}$.

\section{Obmycie paschalne}

Dzięki wykopaliskom archeologicznym prowadzonym po 1967 r. w pobliżu wzgórza świątynnego w Jerozolimie (w bliskości południowych bram prowadzących do świątyni), w dzielnicy żydowskiej Starego Miasta oraz na tzw. Wzgórzu Zachodnim, odnaleziono małe baseniki przeznaczone do obmyć stóp umiejscowione przy dużych basenach (miqwa'ot) służących do rytualnych obmyć

29 Schneiders, „The Foot Washing”, 84-88. F.J. Moloney, „A Sacramental Reading of John 13:138", CBQ 53 (1991) 249 zaproponował wprowadzenie jeszcze czwartego modelu posługi, a minowicie: ,a love unto death of friends who have betrayed and denied the one who loves still".

30 Mathew, The Johannine Footwashing. 
całego ciała. Odkrycie to wskazuje na powszechność praktyki obmywania stóp w czasach Jezusa i pozwala lepiej zrozumieć tekst: „wykąpany potrzebuje tylko nogi sobie umyć, bo cały jest czysty" (J 13,10). Możemy zatem przypuścić, że kąpiel, o której mowa w 13,10, odnosi się do rytualnej kąpieli całego ciała poprzedzającej wieczerzę paschalną (zob. J 11,55; 13,1). Sam gest umycia nóg natomiast byłby już tylko uzupełnieniem tejże rytualnej kąpieli - uzupełnieniem, które było dobrze znane w ówczesnej kulturze ${ }^{31}$. Wyjaśnienie powyższe nie jest jednak użyteczne w egzegezie całości perykopy J 13,1-20, gdyż nie pozwala wyjaśnić wszystkich elementów tego tekstu, których pełną listę przedstawimy poniżej.

\section{Polemika z rytami ekonomii starotestamentowej}

W świetle zarysowanego powyżej kontekstu archeologiczno-historycznego nie przekonują również propozycje widzące w czynności Jezusa polemikę, krytykę czy wręcz odrzucenie żydowskich rytów oczyszczających: Jezusowe umycie nóg miałoby demonstrować niewystarczalność rytu wykąpania całego ciała ${ }^{32}$. Jezus nie mógł odrzucić rytu umycia ciała, gdyż w pełni wykorzystał - jak wiemy z odkryć archeologicznych - uzupełniający go ryt umycia nóg. Dalsza analiza pokaże również, iż Jezus i Jego uczniowie (a dalej wspólnota stojąca za powstaniem czwartej Ewangelii) nadali powszechnie praktykowanemu rytowi umycia nóg nową treść. Jezus w czwartej Ewangelii nie tyle odrzuca ryty starotestamentowe, ile je zastępuje (R.E. Brown), dopełnia i przekracza (F.J. Moloney) ${ }^{33}$.

\subsection{Niewystarczalność interpretacji dosłownych}

Okazuje się, że interpretacja dosłowna, odwołująca się do tła kulturowego, nie harmonizuje ze wszystkimi elementami tekstu Janowego. Ten brak harmonii, czy też zauważalna niezgodność między interpretacją dosłowną a tekstem Janowym, sugeruje istnienie - zamierzonego przez autora - symbolicznego, w tym także sakramentalnego, znaczenia gestu Jezusa. Poniżej zostaną przedstawione najważniejsze argumenty krytyków interpretacji dosłownej.

31 G. Giurisato, „John 13:10: An Archaeological Solution of Textcritical Problem”, LASBF 58 (2008) 73-80.

32 A. Fridrichsen, „Bemerkungen zur Fusswaschung Joh 13”, ZNW 38 (1939) 94-96; O. Betz, „Die Proselytentaufe der Qumransekte und die Taufe im NT", Revue Qumran 1 (1958) 213-324.

33 Zob. R.E. Brown, An Introduction to the Gospel of John. Edited, Updated, Introduced, and Concluded by Francis J. Moloney (The Anchor Bible Reference Library; New York, NY et al:: Doubleday 2003) 76-77. 
(1) Wiersze 13,6-10 wskazują, iż umycie nóg jest konieczne dla uczniów, aby mieli udział z Jezusem (w. 8). Czy pokorna służba lub też gościnność jest tą koniecznością, wyłącznym mechanizmem, tudzież nieodzownym środkiem, który pozwala mieć udział w dziedzictwie z Jezusem? Można mieć wątpliwości.

(2) Istotne jest dostrzeżenie, iż to nie duch popychający Jezusa do tego gestu (bez względu na to, czy będzie to pokora, służba, czy miłość), ale umycie stóp, samo w sobie, jest konieczne dla posiadania dziedzictwa z Jezusem. Nie tyle zatem motywacja do wykonania gestu, ile skutki wykonania gestu zajmują centralne miejsce $\mathrm{w}$ interpretacji wydarzenia.

(3) Termin $\mu$ śpo (w. 8), który tłumaczymy w tekście Janowym jako „udział”, odpowiada w greckim tłumaczeniu LXX hebrajskiemu sformułowaniu określającemu terytorialny udział w podziale Ziemi Obiecanej (Lb 18,20; Pwt 12,12; 14,27). W niektórych psalmach „dziedzictwem” (pochodny termin $\mu \varepsilon \rho i ́ s)$ pobożnego Izraelity jest już jednak sam Bóg $(15,5 ; 72,26$; $118,57 ; 141,6)$. Nie dziwi zatem, iż w Corpus Johanneum występuje słowo $\mu \varepsilon ́ \rho \varsigma \varsigma$, które określa udział w wiecznym, eschatologicznym dziedzictwie niebiańskim (Ap 20,6; 21,8; 22,19). W istocie Jezus mówi o „dziedzictwie z Nim" ( $\mu \varepsilon \dot{\varepsilon} \rho \varsigma \varsigma \varepsilon \tau$ ' $\dot{\varepsilon} \mu o \tilde{v})$, a zatem o dziedzictwie przynależącym zarówno do uczniów, jak i do Niego samego $(13,8)$. Ideę uczestniczenia uczniów w chwale nieba z Jezusem spotykamy w Janowym opisie Ostatniej Wieczerzy $(14,3 ; 17,24$; por. Łk 22,30; 23,43). W efekcie obmycie nóg sprawia, iż uczniowie mają udział z Jezusem w życiu wiecznym. Czynność ta ma zatem sens zbawczy, soteriologiczny. Taka konkluzja nie harmonizuje z rozumieniem umycia nóg jako zwykłego aktu pokory czy też gościnności ${ }^{34}$.

(4) Reakcja Piotra, który protestuje przeciwko umyciu mu nóg, wydaje się doskonale zrozumiała jako wyraz jego szczerego zakłopotania wobec

34 Powyższe trzy intuicje odpowiadają po części wątpliwościom, jakie miał już Orygenes (Commentarium in Joannem 32,5), który ostatecznie odszedł od literalnego tłumaczenia gestu Jezusa: „Zgodnie z przeczuciem, jakie [uczniowie] mieli odnośnie do Jezusa, wiedzieli, że On umywa ich nogi nie bez ważnego powodu i nie chce, jakby to wielu powiedziało, obciążać uczniów, lecz ma na celu jakąś ich korzyść, którą mieli poznać dopiero w przyszłości. Zastanawiam się więc, czy nie wprowadza On może jakiegoś symbolu". Za: Orygenes, Komentarz do Ewangelii według św. Jana (tłum. S. Kalinkowski) (Źródła Myśli Teologicznej 27; Kraków: WAM 2003) 513-514. W nieco innym duchu komentuje współczesny autor, dochodząc jednak do tych samych konkluzji: „If there were nothing more at stake then the naked act of footwashing, Jesus' response would seem petty, unbearably rigid. It would sound like fake humility: «I command you to let me be humble and let me wash your feet - or your're fired!» But once the symbolism is seen, Jesus' words are almost inevitable: Unless I wash you, you have no part with me". D.A. Carson, The Gospel according to John (Pillar New Testament Commentary; Leicester, U.K.: Apollos/Grand Rapids, MI - Cambridge, U.K.: Eerdmans 1991) 463-464. 
anormalnej sytuacji odwrócenia ról: mistrz-uczeń. Jezusowa ocena odmowy Piotra wydaje się jednak niewspółmierna do „winy” Piotra. Jezus definiuje bowiem odmowę Piotra jako odmowę udziału ( $\mu \varepsilon ́ \rho \varsigma_{\text {) }}$ w życiu wiecznym, a nie jako proste sprzeciwienie się odwróceniu ról. Jezusowa ocena postawy Piotra wskazuje na dużo głębsze znaczenie gestu obmycia nóg - znaczenie zbawcze ${ }^{35}$.

(5) Jezus stwierdza, że to On sam musi umyć Piotra (J 13,8). Nie chodzi tu zatem tylko i wyłącznie o posługę mycia nóg, jaką mają sobie nawzajem świadczyć uczniowie, a tym samym o przykład, jaki dał Jezus. Tekst Janowy mówi o szczególnym geście Jezusa mającym znaczenie wykraczające poza przykład czynności, którą mogliby wykonywać sami uczniowie. Gest Jezusa ma zatem znaczenie wyjątkowe, bo może być wykonany tylko przez Jezusa. Konsekwentnie - czynność ta musi mieć głębszy sens niż przykład do naśladowania i winna mieć znaczenie zbawcze.

(6) Umycie nóg jest dodatkowym oczyszczeniem (w. 10). Mamy zatem do czynienia z dwoma obmyciami: ogólną kąpielą (określoną przez ó $\lambda \varepsilon \lambda o v \mu \varepsilon ́ v o \varsigma$ ) oraz późniejszym, szczegółowym, dodatkowym umyciem stóp (wyrażonym przez ví $(\alpha \sigma \theta \alpha$ l). Tekst perykopy nie daje żadnej wskazówki, jaki jest sens ogólnego umycia. Istnienie dwóch rodzajów obmycia w tekście sugeruje zatem dwie oddzielne rzeczywistości. Innymi słowy, wydaje się prawdopodobne, iż ogólne umycie odnosi się do innej rzeczywistości niż umycie nóg. Jeśli umycie nóg jest przykładem pokory, służby i miłości, to czym jest ogólne umycie? Odwołując się do kontekstu archeologicznego, według którego umycie nóg było uzupełnieniem całościowej kąpieli, obie czynności mogą wyrażać jedną rzeczywistość. Czy można jednak narzucić rytualnemu ogólnemu obmyciu całego ciała sens narzucony przez umycie nóg, którym byłaby pokora, służba i miłość? Czy niedostatek pokory uczniów (obmycie ogólne) ma być zestawiony z pokorą Jezusa (umycie nóg)? Wskazanie na

35 Schneiders, „The Foot Washing”, 83. Autorka ta przyrównuje ten brak proporcjonalności między „winą” Piotra a „karą” deklarowaną przez Jezusa ze synoptyczną sceną, w której Jezus nazywa Piotra „Szatanem” (Mk 8,32-33; Mt 16,22-23): „In both scenes Peter is presented as having taken a stance diametrically opposed to Jesus' salvific mission". Oddajmy raz jeszcze głos Orygenesowi (Commentarium in Joannem 32,8), który również usprawiedliwiał interpretację symboliczną odwołując się do sensu dialogu Jezusa z Piotrem w w. 8: „Ci, którzy zastanawiają się nad zdaniem: „Tego, co Ja czynię, ty teraz nie rozumiesz, ale później będziesz to wiedział”, oraz: „Jeśli cię nie umyję, nie będziesz miał udziału ze Mną”, a nie chcą tych i tym podobnych wypowiedzi rozumieć alegorycznie, niechaj zawstydzeni zgodzą się jednak na taki właśnie sposób interpretacji tekstów ewangelicznych. Albo, jeśli nie chcą się na to zgodzić, niechaj dowiodą, że zgodnie z ich opinią słuszne jest, aby człowiek, który z szacunku dla Jezusa powiedział Nauczycielowi: „Nigdy nie będziesz mi nóg umywał”, usłyszał, że nie będzie miał udziału z Synem Bożym, tak, jakby ciężkim grzechem był brak zgody na to, aby mu Jezus umył nogi”. Za: Orygenes, Komentarz, 518. 
dwie różne rzeczywistości, symbolizowane przez dwa różne obmycia, wydaje się bardziej logiczne.

(7) Gdyby chodziło jedynie o przykład pokornej służby czy gościnności, Piotr byłby w stanie natychmiast to zrozumieć, tak jak rozumieją to inni uczniowie (w. 12 i 17). Piotr tymczasem zrozumie ten gest później (w. 7). Umycie nóg musi zatem oznaczać coś innego niż tylko przykład pokory, służby czy gościnności.

(8) Co istotne, wymowa w. 7 wskazuje, że Piotr rozumie znaczenie gestu, a nie ducha (np. ducha pokory), który ten gest inspirował.

(9) Słowa Piotra - „Panie, nie tylko nogi moje, ale i ręce, i głowę!” (w. 9) wskazują, iż Piotr rozumie obmycie dokonane przez Jezusa, jako będące czymś więcej niż tylko gestem pokory sługi/niewolnika obmywającego nogi. W błędnym mniemaniu Piotra większa liczba obmyć, czy też większy ich zakres (ręce, głowa), będzie skutkował większym udziałem w dziedzictwie z Jezusem. W odpowiedzi Jezus stwierdza, iż tylko obmycie nóg ma znaczenie. Jaki zatem ma ono walor? Powyżej już zauważyliśmy, iż jest to czynność wyjątkowa, gdyż dokonuje go sam Jezus. Ma także inny sens niż ogólna kąpiel, o której mowa w w. 10. Jednak przede wszystkim obmycie to jest gestem zbawczym, gdyż daje udział w dziedzictwie z Jezusem (w. 8).

(10) Jezus, nazywając Piotra „czystym” (w. 10), pomimo uprzedniej wiedzy o przyszłym potrójnym zaparciu się Jezusa (w. 38), nie mówiłby o pozbawieniu Piotra „udziału” (w. 8), czyli życia wiecznego, z powodu Piotrowej niechęci czy braku zgody na demonstrację przykładu pokory, gościnności, służby czy miłości. Tolerancja Jezusa dla Piotrowej zdrady staje się niezrozumiała w świetle Jezusowej nietolerancji dla Piotrowej odmowy przyjęcia prostego gestu umycia nóg mającego być jedynie przykładem pokory czy służby. Gest ten musi być zatem czymś więcej niż tylko demonstracją Jezusowej pokory, gościnności, służby czy miłości ${ }^{36}$.

(11) Stwierdzenie Jezusa: „I wy jesteście czyści, ale nie wszyscy” (w. 10) musi się odnosić do rzeczywistości duchowej, a nie do zwykłego umycia nóg. Jeśli przyjmiemy tutaj odniesienie do zwykłego fizycznego umycia, wówczas jeden z uczniów nie wykąpał się przed przybyciem na ucztę lub też Jezus nie umył mu stóp. Powyższe naturalistyczne wyjaśnienia nie wydają się logiczne w kontekście całej narracji. Wyjaśnienie duchowe najbardziej przekonuje, gdyż sam narrator wskazuje, iż nieczystość ta odnosi się do rzeczywistości innej niż umycie, a mianowicie do rzeczywistości duchowej jaką jest zdrada: „Wiedział bowiem, kto Go wyda, dlatego powiedział: „«Nie

36 Schneiders, „The Foot Washing”, 83. 
wszyscy jesteście czyści»” (w. 11). Innymi słowy, termin „czysty” ma dwa znaczenia, dosłowne i duchowe, w ramach tej samej narracji.

(12) Nigdzie w czwartej Ewangelii Jezus nie jest przedstawiony jako wykonujący jakąś czysto praktyczną posługę w stosunku do innych. Nawet jeśli Jezus dostarcza wina w Kanie - co jest praktyczną posługą - Ewangelista opisuje Go w roli mesjańskiego Oblubieńca. Praktyczna posługa ma zatem chrystologiczny sens. W czwartej Ewangelii Jezus w stosunku do uczniów jest Bogiem, Panem, Nauczycielem, Pasterzem, Przyjacielem, Bratem, ale nie jest sługą czy niewolnikiem. Synoptyczny obraz Jezusa-Sługi nie odpowiada zatem do końca Janowej chrystologii czy też Janowej charakteryzacji Jezusa.

(13) Ewangelista używa czasownika $\tau i ́ \theta \eta \mu \iota ~(13,4)$ na określenie czynności zdjęcia wierzchnich szat przez Jezusa. Termin ten niezwykle rzadko bywa

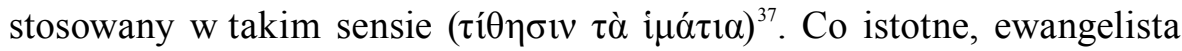
określa za pomocą tego terminu oddanie życia za owce przez Dobrego Pasterza $(10,11.15 .17 .18$ bis $)$ oraz oddanie życia za przyjaciół przez przyjaciela $(15,13)$. Tym samym czasownikiem wyrażone jest również oddanie życia za Jezusa przez Piotra, w bezpośrednim kontekście literackim opisu umycia nóg $(13,37.38)^{38}$. Równie niecodziennym jest użycie czasownika $\lambda \alpha \mu \beta \alpha ́ v \omega$

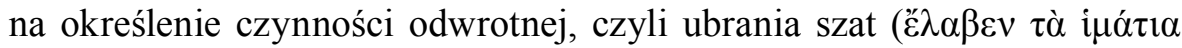
- 13,12). Specyficzne użycie tego czasownika ponownie znajduje swoją paralelę w perykopie o Dobrym Pasterzu, gdzie termin ten również opisuje odzyskanie życia przez Pasterza $(10,17.18)^{39}$.

37 W NT i LXX nie ma paraleli dla takiego użycia tego czasownika w stronie czynnej. Znajduje

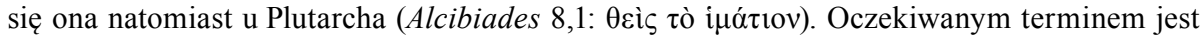

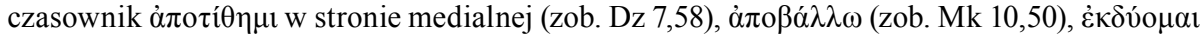
(zob. $1 \mathrm{Sm} \mathrm{19,24} \mathrm{LXX;} \mathrm{por.} \mathrm{Mt} \mathrm{27,28.31)} \mathrm{lub} \mathrm{inne} \mathrm{czasowniki} \mathrm{pochodne} \mathrm{od} \mathrm{\delta v́o \mu \alpha t.}$

38 Warto także zwrócić uwagę na paralelę w $1 \mathrm{~J} 3,16$, gdzie czasownik ten opisuje oddanie życia przez Jezusa za ludzi oraz oddanie życia przez wierzącego za swego brata w wierze.

39 Również w tym przypadku nie ma paraleli w NT i LXX dla użycia tego czasownika w zna-

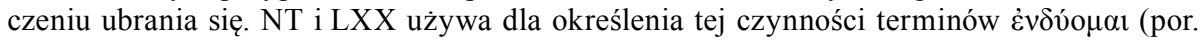

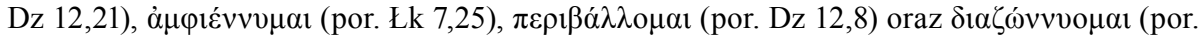
J 21,7). Przywoływane przez BAGD 465 paralele w dziele Herodota Historiae (2,37 oraz 4,78) nie są właściwe, gdyż nie odnoszą się do fizycznego założenia ubrania, ale do przyjęcia odpowiedniego stylu ubierania się. Bardzo możliwe, iż Janowe niecodzienne użycie czasowników $\tau i ́ \theta \eta \mu \iota$ oraz $\lambda \alpha \mu \beta \alpha ́ v \omega$ można wyjaśnić jako latynizmy: vitam ponere oraz animam ponere, w sensie „oddać życie”, mogą odpowiadać wyrażeniom vestem ponere „zdjąć ubranie” oraz vestem capere „nałożyć ubranie”. Zob. R.B. Edwards, „The Christological Basis of the Johannine Footwashing", Jesus of Nazareth: Lord and Christ. Essays on the Historical Jesus and New Testament Christology (red. J.B. Green - M. Turner) (Grand Rapids, MI: Eerdmans 1994) 372. Autorka ta stwierdza (Ibidem, 373): „Garments are indeed often used with symbolic significance in the ancient world, and reclothing is a frequent symbol of new status, both socially and spiritually. It would therefore seem quite reasonable to understand in John's use of these verbs an indirect allusion to Jesus voluntarily laying aside his life on the cross, and resuming it in the resurrection". 
(14) Bardzo możliwe, iż ewangelista użył czasownika $\delta \iota \zeta \omega ́ v v v \mu ı$ w sensie symbolicznym. Termin ten, będąc Janowym hapax legomenon w NT i LXX, określa opasanie prześcieradłem Jezusa (w 13,4.5) i Piotra (w 21,7). W przypadku Piotra termin ten określa jego męczeńską śmierć. Stąd można domniemywać, iż czasownik ten ma w opisie umycia nóg podwójne znaczenie: uniżenie w posłudze niewolnika ${ }^{40}$ oraz męczeńską śmierć krzyżową. Byłby to kolejny przykład częstej Janowej techniki double entendre ${ }^{41}$.

(15) Najbliższy kontekst literacki opisu gestu, a mianowicie odwołanie do nadejścia „godziny” (13,1) oraz miłości swoich „,do końca” $(13,1)$, może również sugerować ponaddosłowne rozumienie gestu Jezusa. Oba elementy wskazują na związek umycia nóg ze śmiercią Jezusa. Temat śmierci współgra także z gatunkiem literackim J 13-17, którym jest mowa pożegnalna. W gatunku tym występuje bowiem temat śmierci osoby żegnającej się. Śmierć ta jest powodem zgromadzenia innych wokół tej osoby (Testament Rubena 1,3-5; Testament Lewiego 1,2; Testament Dana 2,1; Testament Mojżesza 1,15), a sam testament wypowiadany jest w kontekście uczty (Testament Neftalego $1,2-5,9,2)^{42}$

(16) Interpretacje dosłowne odwołujące się do starożytnego gestu umycia nóg jako znaku powitania i gościnności (por. C. Niemand, A.J. Hultgren, M.L. Coloe) napotykają trudność chronologiczną. Otóż Jezusowa czynność obmycia nóg następuje nie na początku uczy, ale w jej trakcie. Sam fakt przeniesienia rytu z początku uczty w jej środek (o tym, że był to posiłek, czytamy w w. 4), nadaje temu gestowi walor symboliczny ${ }^{43}$.

Powyższe uwagi wskazują, iż duchowa/ponaddosłowna (czy to symboliczna czy też sakramentalna) interpretacja gestu Jezusa ma podstawy w samym tekście. Wniosek ten potwierdzony jest także historią egzegezy badanego tekstu Janowego. Otóż wśród starożytnych chrześcijańskich pisarzy łacińskich właśnie

40 Przepasanie się prześcieradłem było w starożytności znakiem wykonywania posługi niewolnika. Znamy przynajmniej dwa przykłady z literatury starożytnej, gdzie przepasanie się prześcieradłem miało znaczenie symboliczne, a mianowicie oznaczało zmianę statusu osoby wolnej na niewolnika: Swetoniusz, Vita Caligulae 26 oraz Midrasz Rabba do Rdz 21,14.

41 Dwa inne znaczenia symboliczne przepasania bioder (jako znak paschy oraz walki zapaśnika) omawia F. Manns, „Le lavement des pieds: essai sur la structure et la signification de Jean 13”, RevSR 55 (1981) 164-166.

42 Odniesienia do bibliografii dotyczącej mów pożegnalnych w F.J. Moloney, The Gospel of John (Sacra Pagina 4; Collegeville, MI: The Liturgical Press 1998) 377.

43 Pesce, ,Il lavaggio dei piedi (Gv 13,1-20)”, 239: ,collocando il lavaggio in um momento imprevedibile, svuotandolo della sua funzione ordinaria, Gesù lo trasforma necessariamente in un gesto di alto valore simbolico. Lo rende rappresentazione o veicolo di un modello comportamentale e simbolico nuovo". Autor ten sugeruje, iż Jezus i uczniowie mogli dokonać obmycia nóg już w momencie wejścia do domu i przed rozpoczęciem wieczerzy. Gest Jezusa byłby zatem powtórnym aktem umycia nóg uczniom, mającym już jednak znaczenie symboliczne. 
na sposób symboliczny i sakramentalny tłumaczono Jezusowy gest umycia uczniom nóg. Na Zachodzie dopiero w XVI w. pojawiła się interpretacja wyłącznie dosłowna odwołująca się do zwyczajów orientalnych (np. gest Jezusa jest wymogiem gościnności ${ }^{44}$. Najprawdopodobniej powstanie tej interpretacji było reakcją na twierdzenia anabaptystów widzących w umyciu nóg (pedilavium) kolejny sakrament chrześcijański. Na Wschodzie, wśród starożytnych pisarzy greckich, interpretacja dosłowna była dominująca i w wielu przypadkach był to jedyny sposób wyjaśniania Janowego tekstu (np. Jan Chryzostom), choć byli tam także autorzy preferujący wyjaśnienie symboliczne ${ }^{45}$.

Tomasz z Akwinu mówi o istnieniu jednocześnie dwóch sensów umycia nóg, dosłownym (cielesnym) i mistycznym (duchowym), łącząc umiejętnie tradycję interpretacyjną Wschodu i Zachodu. Komentując J 13,5, Tomasz stwierdza, że w sensie dosłownym gest Jezusa jest wyrazem Jego pokory. W sensie mistycznym natomiast umycie nóg oznacza ofiarę krwi Jezusa, która oczyszcza Jego uczniów z grzechów i jest wstępem do chrztu w Duchu Świętym ${ }^{46}$. Komentując J 13,14 „wy powinniście sobie nawzajem umywać nogi” - Akwinata stwierdza, iż można je umywać na dwa sposoby: cielesny i duchowy. W pierwszym - chrześcijanin dosłownie służy bratu, obmywając jego ciało, przez co naśladuje Jezusową cnotę pokory. W drugim - chrześcijanin obmywa brata ze zmazy grzechu ${ }^{47}$.

Także Cornelius à Lapide (zm. 1637) wprowadził rozróżnienie dosłownego i symbolicznego sensu aktu Jezusa, mówiąc o dwóch uzupełniających się znaczeniach. Według jego egzegezy na poziomie dosłownym mowa jest o kąpieli całego ciała i następującym potem zabrudzeniu stóp i potrzebie ich umycia. Byłoby to zatem odwołanie do zwyczajów bliskowschodnich. Na poziomie duchowym natomiast ogólna kąpiel winna być rozumiana jako sakrament chrztu lub pokuty (jako gładzące każdy grzech), umycie nóg zaś jako skrucha (żal za grzechy), cielesna asceza i cnoty, które usuwają lekkie grzechy, umożliwiając przyjęcie Eucharystii ${ }^{48}$. Autor ten wprowadza pewne novum, gdyż do XVI w. wśród pisarzy łacińskich nikt w tłumaczeniu sensu dosłownego nie szukał paraleli w starożytnych zwyczajach orientalnych. Akwinata, jak widzieliśmy, w wyjaśnieniu sensu dosłownego poprzestał jedynie na uniwersalnym i ponadczasowym przykładzie pokory, dla którego zrozumienia nie jest konieczna

44 Pojawienie się takiej interpretacji zanotował w swym komentarzu Joannes Maldonatus (zm. 1583). Zob. Commentarii in quatuor evangelistas (Moguntiae: Birckman 1651) 1711D.

45 Przykładem może być odwołanie do chrztu u Orygenesa (Commentarium in Joannem 32,4-5; PG 14,751-752) i Afrahata (Demonstrationes 12,10).

46 Święty Tomasz z Akwinu, Komentarz do Ewangelii Jana (tłum. T. Bartoś) (Biblioteka Europejska; Kęty: Marek Derewiecki 2018) 818-819.

47 Święty Tomasz z Akwinu, Komentarz, 830.

48 C. à Lapide, Commentaria in Scripturam Sacram. XVI. In SS. Lucam et Joannem (Paris: Ludovicus Vivès 1867) ad loc. 
znajomość kultury starożytnej. Św. Tomasz, posługując się metodą egzegezy wewnątrzbiblijnej (Biblia komentuje Biblię), w istocie odwołuje się jedynie do słów Jezusa, definiujących Jego misję jako posługę (por. Mt 20,28). Poczynając od C. à Lapide'a, spojrzenie na J 13,1-20 poprzez pryzmat dwóch sensów, wyrazowego oraz duchowego, z szukaniem jednak sensu dosłownego w specyficznych dla starożytności zwyczajach, stawało się coraz bardziej popularne ${ }^{49}$.

$\mathrm{W}$ pierwszej połowie XX w. pojawił się jeszcze inny motyw hermeneutyczny usprawiedliwiający istnienie dwóch interpretacji gestu Jezusa. Otóż, w świetle analizy historyczno-krytycznej, odwołującej się do metod Traditionsgeschichte oraz Redaktionsgeschichte, czwarta Ewangelia powstawała w wyniku złożonego procesu redakcyjnego. W efekcie, w finalnej wersji Ewangelii znalazły się teksty pochodzące $\mathrm{z}$ różnych tradycji, mające także różnych autorów (w tym redaktorów) i pochodzące z różnych okresów rozwoju Wspólnoty Janowej. Wówczas, poczynając od R. Bultmanna (1941) i E.C. Hoskynsa (1947), narodził się pogląd, w świetle którego tekst J 13,1-20 składa się z dwóch części, będąc dyptychem prezentującym dwie różne interpretacje tego samego gestu ${ }^{50}$. Zwykło się także uważać, iż każde ze skrzydeł tego dyptychu pochodzi z innego okresu formowania się Wspólnoty Janowej, odzwierciedlając różne etapy rozwoju jej teologii. Do tego nowego motywu hermeneutycznego, skutkującego jednoczesnym dostrzeganiem dwóch interpretacji tekstu J 13,1-20, wrócimy jeszcze w kluczowej części naszego wywodu.

Druga połowa XX w. przyniosła jeszcze jedną istotną modyfikację podejścia do tekstu Ewangelii Janowej, która ma swe konsekwencje w interpretacji Jezusowego gestu umycia nóg. Otóż stwierdzono, iż słowa i gesty Jezusa, zanim zostały opisane na kartach czwartej Ewangelii, były wielokrotnie opowiadane, a przy tym przepracowywane i modelowane $\mathrm{w}$ różnych kontekstach ${ }^{51}$. W konsekwencji tekst Janowej Ewangelii jest kompilacją głównie ustnego materiału (powstałego w dłuższym okresie czasu i w różnych kontekstach historycznych), który zawiera różne interpretacje tych samych wydarzeń i słów. Powyższa charakterystyka tekstu Janowego sprawia, iż nie można go czytać jak współczesnego tekstu charakteryzującego się logiczną koherencją (logical unity, narratological

49 Przykładem niech będzie praca J.J. Wettsteina (zm. 1754), który podaje przykłady obmyć przed posiłkiem zaczerpnięte z literatury klasycznej, a jednocześnie mówi o sensie mistycznym narracji Janowej, za który uważa chrzest. Zob. J.J. Wettstein (Wetstenius), Novum Testamentum graecum editionis receptae cum lectionibus variantibus codicum mss. editionum aliarum, versionum et patrum necnon commentario pleniore ex scriptoribus veteribus hebraeis, graecis et latinis (Amstelaedami: Ex officina Dommeriana 1751) I, 929: „Sensus mysticus est: «Ita et vos per baptismum abluti estis»".

50 R. Bultmann, Das Evangelium des Johannes (KEK; Göttingen: Vandenhoeck \& Ruprecht ${ }^{10} 1968$ ) 351-365 (pierwsze wydanie ukazało się w 1941) oraz u E. Hoskyns, The Fourth Gospel (red. F.N. Davey) (London: Faber \& Faber 1947) 436-439.

51 Zob. B. Olsson, Structure and Meaning in the Fourth Gospel. A Text-Linguistic Analysis of John 2:1-11 and 4,1-42 (CB.NT 6; Lund: Gleerup 1974) 256-274. 
unity). Współcześni komentatorzy czwartej Ewangelii mówią zatem o redakcyjnej jedności (editorial unity) tekstu tejże Ewangelii, wykluczając narracyjnie logiczną sekwencję słów i wydarzen ${ }^{52}$. W konsekwencji Jezusowy gest umycia nóg, $\mathrm{w}$ formie tekstualnej zawartej w finalnej wersji czwartej Ewangelii, ma z zasady wiele znaczeń i niemożliwym jest mówienie o właściwym czy prawdziwym znaczeniu tekstu. Można jedynie pokusić się o stworzenie listy różnych sensów tekstu ułożonych w chronologicznej kolejności ich powstawania ${ }^{53}$.

\section{Interpretacje symboliczne}

W istocie cały tekst czwartej Ewangelii jest symboliczny, gdyż kieruje na rzeczywistość objawiającego się Boga (por. J 20,29) ${ }^{54}$. W sposób szczególny symboliczne znaczenie posiadają Janowe „znaki” ( $\sigma \eta \mu \varepsilon i \alpha)$, do których obok męki, śmierci i zmartwychwstania Jezusa zaliczyć należy także gest umycia nóg. Gest ten jest znakiem par excellence, gdyż objawia on znaczenie dzieła zbawienia. Jak zauważa S.M. Schneiders, symboliczny sam w sobie akt umycia nóg nabrał ponownie cech symbolicznych poprzez sam fakt utrwalenia go na kartach Ewangelii ${ }^{55}$. Innymi słowy, gest umycia nóg, będąc symbolicznym znakiem dla pierwszych uczniów, stał się takim znakiem dla wszystkich czytelników Ewangelii poprzez fakt zapisania go na kartach tejże księgi. Ten gest, posiadający znaczenie symboliczne, stał się źródłem nieustającej refleksji kolejnych pokoleń czytelników Ewangelii, którzy z wrażliwością właściwą danej epoce poszukują istoty zbawienia ${ }^{56}$.

52 Zob. H.U. von Wahlde, The Gospel and Letters of John. I. Introduction, Analysis, and Reference (Eerdmans Critical Commentary; Grand Rapids, MI - Cambridge, U.K.: Eerdmans 2010) 35-36.

53 B. Olsson, „The Meanings of John 13,10: A Question of Genre?”, Studies in the Gospel of John and its Christology. Festschrift Gilbert Van Belle (red. J. Verheyden - G. van Oyen - M. Labahn) (BETL 265; Leuven - Paris - Walpole, MA: Peeters 2014) 317-325. Na ostatniej stronie swego tekstu Olsson stwierdza: „In my view, it is impossible to talk about the original meaning of Jn 13,10. There are several meanings woven into each other. This is characteristic feature of the Johannine Gospel as a genre. It may be possible to create a temporal order of the different meanings, but these are still parts of the Johannine text. Logical or narratological coherence as a premise of our readings of the Gospel of John is not a fruitful approach".

54 Przez symbol rozumiem jakikolwiek konkretny znak, który przywołuje, poprzez naturalny związek, coś nieobecnego lub coś co nie może być poznane, doświadczone (aliquid stat pro aliquo). G. Durand, L'imagination symbolique (Paris: Presses Universitaires de France 1964) 11: „tout signe concret évoquant, par un rapport naturel, quelque chose d'absent ou d'impossible à percevoir”. Durant idzie tutaj za definicją przedstawioną przez A. Lalande, „Symbole: sens”, Vocabulaire critique et technique de la philosphie (Paris: Alcan 1926) ad loc.

55 Schneiders, „The Foot Washing”, 80: „The symbolic revelation of the act of the foot washing is re-symbolized in the text".

56 Schneiders, „The Foot Washing”, 80: „the foot washing is not an event which has a single, univocal meaning coterminous with the intention of the fourth evangelist and / or the understanding 
Wśród interpretacji symbolicznych najczęściej widzi się gest Jezusa jako znak Jego pokory, który ostatecznie interpretuje krzyż. Dla E.C. Hoskynsa, który w czasach nowożytnych jako pierwszy zaproponował takie wyjaśnienie, czyn Jezusa jest komentarzem do J 12,20-26, ukazującym służbę jako jedyny gwarant życia wiecznego. Służba Jezusa i służba Jezusowi oznacza doskonałe posłuszeństwo Ojcu, oddanie swojego życia i w efekcie otrzymanie życia wiecznego. W konsekwencji gest Jezusa interpretuje Jego śmierć krzyżową. Ukrzyżowanie było bowiem znakiem najwyższej pokory Jezusa, rozumianej jako służba wyrażająca się w posłusznym oddaniu życia. Jeśli następuje tutaj oczyszczenie, to jest to oczyszczenie z grzechów dokonane krwią Jezusa ${ }^{57}$. $\mathrm{W}$ swej esencji interpretacja ta obecna jest explicite w wielu miejscach komentarza Tomasza z Akwinu, który stwierdza, m.in.: „«Po tym, jak umył im nogi» [J 13,12], czyli gdy wypełniło się oczyszczenie przez krew"s8. Skrótowo można streścić tę interpretację $\mathrm{w}$ stwierdzeniu, iż umycie uczniom nóg jest metaforą krzyża $^{59}$. Propozycja ta stała się obecnie dominującym sposobem wyjaśniania sensu gestu Jezusa ${ }^{60}$.

of his original audience, but that is a symbol, endlessly giving rise to reflection, generating an ever deeper understanding of the salvation it symbolizes as the horizon of the text focuses with the various horizons of generations of readers". Hermeneutyczne refleksje amerykańskiej egzegetki odwołują się do ustaleń obecnych w pracach Paula Riceoura, m.in. The Conflict of Interpretations. Essays in Hermeneutics (red. D. Ihde) (Studies in Phenomenology and Existential Philosophy; Evanston, IL: Northwestern University Press 1974).

57 Hoskyns, The Fourth Gospel, 424, 435-437.

58 Święty Tomasz z Akwinu, Komentarz, 827. Komentując J 13,5, Akwinta (Komentarz, 819) stwierdza: „Pan nalewając wody do miednicy, wskazuje na przelanie swej krwi, a obmywając nogi uczniom, na obmycie nas z grzechów".

59 J. Zumstein, L'évangile selon saint Jean (13-21) (Commentaire du Nouveau Testament. Duxième série 4b; Genève: Labor et Fides 2007) 33: „le levement des pieds est la métaphore de la croix”. Por. także Barrett, John, 436 (,the washing of the disciples' feet, which prefigures the crucifixion itself, and in doing so points the way to the interpretation of the crucifixion."); J.D.G. Dunn, „The Washing of the Disciples' Feet in John 13,1-20”, ZNW 61 (1970) 248 („,What he [Jesus] is doing $\alpha \rho \tau$ is to act out in parable his coming death on the cross. $\mu \varepsilon \tau \dot{\alpha} \tau \alpha \tilde{v} \tau \alpha$ the Spirit will illuminate the significance of the foot-washing by the light of the cross"); M.M. Thompson, „«His Own Received Him Not»: Jesus Washes the Feet of His Disciples”, The Art of Reading Scripture (red. E.F. Davis) (Grand Rapids, MI: Eerdmans 2003) 266 („,Jesus' act of humble service prefigures Jesus' death on the cross and that the cross rewrites the script for the identity and conduct of Jesus' followers, both corporately and individually").

60 Największe zasługi w jej rozpowszechnieniu i dostarczeniu argumentów za jej przyjęciem miały prace G. Richtera: „Die Fusswaschung Joh 13,1-20”, Münchener Theologische Zeitschrift 16 (1965) 13-26 = „Die Fusswaschung Joh 13,1-20”, Studien zum Johannesevangelium (red. J. Hainz) (Biblische Untersuchungen 13; Regensburg: Pustet 1977) 42-57; Die Fusswaschung im Johannesevangelium. Gesichte ihrer Deutung (Biblische Untersuchungen 1; Regensburg: Pustet 1967). Sumaryczną dyskusję nad tą interpretacją prezentuje D. Gibson, „The Johannine Footwashing and the Death of Jesus: A Dialogue with Scholarship", The Scottish Bulletin of Theology 25/1 (2007) 50-60. 
Poszczególni autorzy podkreślają i rozwijają pewne aspekty powyższego wyjaśnienia. Dla przykładu, wielu komentatorów akcentuje efekt śmierci krzyżowej, jakim było oczyszczenie uczniów z grzechów: umycie nóg to symbol zgładzenia grzechów w śmierci krzyżowej ${ }^{61}$. J. Beutler uważa, że gest wskazuje, jak ważne jest zinterioryzowanie krzyża Jezusa jako najbardziej osobistego gestu wyzwolenia. Interioryzacja ta, skutkująca doświadczeniem wyzwolenia, ma dokonać się $w$ wierze ${ }^{62}$. Dla R.A. Culpeppera umycie nóg jest proleptyczną i metaforyczną interpretacją Jezusowej śmierci. Śmierć ta z kolei jest „mode-

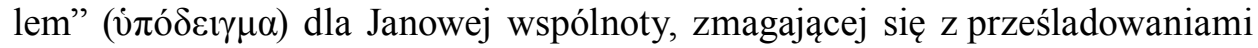
i zagrożeniem utraty życia ${ }^{63}$.

Do interpretacji symbolicznych należy także propozycja Klemensa Aleksandryjskiego i Orygenesa, którzy umycie nóg uczniom widzieli jako przygotowanie uczniów do głoszenia Ewangelii ${ }^{64}$, czy postulat Augustyna, aby widzieć tutaj znak nawracania się i odpuszczania grzechów ${ }^{65}$. Symboliczne jest także wyjaśnienie R. Bultmanna. W jego opinii pierwsza część narracji (gest Jezusa w 13,6-10) to symbol zbawienia prezentującego się w uniżeniu; to symbol samego Boga ukorzonego w formie niewolnika. Poddanie się obmyciu oznacza przyjęcie daru zbawienia, trwanie w jedności ze Zbawicielem, dzielenie Jego przeznaczenia i zmierzanie z Nim do chwały ( $\delta$ ó $\xi \alpha$ ). Przyjęcie daru zbawienia dokonuje się przez wiarę w słowa Jezusa (wiarę w Jezusa-Logos, Objawiciela), które czynią wierzącego czystym $(15,3)$. W drugiej części narracji $(13,12-20)$ Bultmann widzi zachętę Jezusa do pełnej miłości wzajemnej służby. Trwanie we wzajemnej

61 Barrett, John, 436: „The cleansing of the disciples' feet represents their cleansing from sin in the sacrificial blood of Christ $(1.29 ; 19.34)[\ldots]$ the act of washing is what the crucifixion is, at once a divine deed by which men are released from sin and an example which men must imitate". R.E. Brown, The Gospel of John. Introduction, Translation and Notes (Anchor Bible 29A; Garden City, NY: Doubleday 1970) II, 568: „Jesus performed this servile task to prophesy symbolically that he was about to be humiliated in death. Peter's questioning, provoked by the action, enabled Jesus to explain the salvific necessity of his death: it would bring men their heritage with him and it would cleanse them of sin".

62 J. Beutler, Das Johannesevangelium. Kommentar (Freiburg - Basel - Wien: Herder 2013) 383. Komentator ten nie wyklucza odniesienia do chrztu, który wraz z wiarą, jest rzeczywistością poprzez którą Chrystus udziela zbawienia. Z akcentem położonym na wolności i wyzwoleniu, jak tego chce J. Beutler, współgra intuicja M. Pescego (,Il lavaggio dei piedi (Gv 13,1-20)”, 249, przypis 41), iż w J 13,1-20 znajduje się echo starotestamentalnej instytucji jubileuszu: ,una qualche eco dell'utopia socio-religiosa del giubileo levitico".

63 R.A. Culpepper, „The Johannine Hypodeigma: A Reading of John 13”, Semeia 53 (1991) 133-

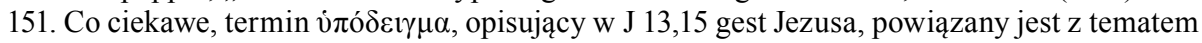
męczeńskiej śmierci w 2 Mch 6,28.31 oraz 4 Mch 17,22-23 (por. także Syr 44,16).

64 Klemens, Paedagogos, II, 8,62,2 (SC 108,128); Orygenes, Commentarium in Joannem 32,4-7 (PG 14,750-774).

65 Tractatus in Joannem 56,2-4 (PL 35,1788). Szczegółowe porównanie interpretacji Orygenesa i Augustyna znajduje się w A. Kadeparambil, Origen and Augustine on John 13. Anagogical And/Or Literal? An Exegetical and Theological Comparison (Bangalore: Asian Trading Corporation 2011). 
miłości jest warunkiem trwania w miłości z Jezusem oraz obecności Jezusa pośród uczniów $^{66}$. J. MacEvilly interpretuje J 13,1-20 symbolicznie jako obmycie przez chrzest, ale także przez wiarę w Jezusa oraz przez posłuszeństwo Jego słowu ${ }^{67}$. F. Spitta rozumie umycie nóg jako nawrócenie i wiarę ${ }^{68}$. C.H. Dodd interpretuje scenę obmycia nóg w połączeniu z Flp 2,6-11 i widzi w niej znak (sign) wcielenia,

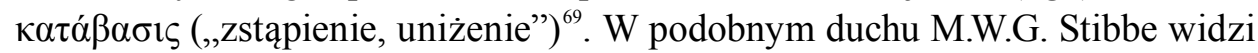
gest Jezusa wstającego od stołu w celu umycia nóg jako zstąpienie z nieba, natomiast powrót Jezusa do stołu po umyciu nóg jako powrót do Ojca w niebie ${ }^{70}$. Po tej samej linii idzie M. D’Agostino, który porównuje wymowę Jezusowego gestu umycia nóg do synoptycznych opisów przemienienia Jezusa: Jezus objawia swoją tożsamość i mówi o swoim odejściu (๕̌ męce i zmartwychwstaniu ${ }^{71}$. B. Schwank wyjaśnia gest Jezusa jako symbol wyrażający jedność uczniów poprzez miłość ${ }^{72}$. J.D.M. Derrett widzi w umyciu nóg znak partnerstwa istniejącego między Jezusem i uczniami ${ }^{73}$. Według J.J. Kanagaraja Jezus umywający nogi to wzór prawdziwego lidera, który swoim przykładem ukazuje istotę przewodzenia i władzy; jest nią wytrwała miłość do drugich, w pokorze i służbie ${ }^{74}$. W podobnym duchu interpretuje Janową perykopę J. Zumstein, widząc w niej dwie relektury początkowego wydarzenia, wpierw przykład paradoksalnego sprawowania władzy, a następnie metaforę krzyża ${ }^{75}$.

66 Bultmann, Johannes, 355-365.

67 J. MacEvilly, An Exposition of the Gospel of St. John (Dublin - New York, NY: Benziger Brothers 1889. $\left.{ }^{2} 1902\right) 262$.

68 F. Spitta, Das Johannes-Evangelium als Quelle der Geschichte Jesu (Göttingen: Vandenhoeck \& Ruprecht 1910) 289.

69 C.H. Dodd, The Interpretation of the Fourth Gospel (Cambridge: Cambridge University Press 1953) 401-402; C.H. Dodd, Historical Tradition in the Fourth Gospel (Cambridge: Cambridge University Press 1965) 62-63.

70 M.W.G. Stibbe, John as Storyteller. Narrative Criticism and the Fourth Gospel (SNTSMS 73; Cambridge: Cambridge University Press 1992) 25. Interpretacja ta jest wyjątkowo „symboliczna", gdyż nie odzwierciedla dokładnie tekstu Ewangelii, który odwzorowuje ówczesny zwyczaj leżenia w czasie posiłków przy niskich stołach. Jezus zatem ,powstał” z pozycji leżącej

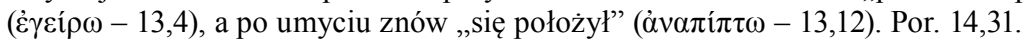

71 M. D’Agostino, „«Si alzò da tavola, depose le vesti» Una trasfigurazione in Gv 13,1-15?”, Il quarto Vangelo (red. C. Doglio) (Parole di Vita 6; Padova: Edizioni Messaggero 2015) 200-206.

72 B. Schwank, „Exemplum dedi vobis. Die Fusswaschung (13,1-17)”, Sein und Sendung 28 (1963) 4-17.

73 J.D.M. Derrett, „The Footwashing in John 13 and the Alienation of Judas Iscariot”, RIDA 24 (1977) 3-19.

74 J.J. Kanagaraj, „Johannine Jesus, the Supreme Example of Leadership: An Inquiry into John 13:1-20", Themelios 29/3 (2004) 15-26.

75 J. Zumstein, „Die johanneische Auffassung der Macht gezeigt am Beispiel der Fusswaschung (Joh 13,1-17)", Recht - Macht - Gerechtigkeit (red. J. Mülhausen) (Gütersloh: Kaiser 1988) 370-385; J. Zumstein, „Le lavement des piedes (Jean 13,1-20): un exemple de la conception johannique du pouvoir”, RThP 132 (2000) 345-360; J. Zumstein, „Le porcessus johannique de la relecture à l'exemple de Jean 13,1-20", Regards croisés sur la Bible. Études sur le point de 
J.A.T. Robinson i H. Weiss uważają, że ten gest jest zapowiedzią męczeńskiej śmierci Jezusa i Jego uczniów, a w konsekwencji zapowiedzią męczeństwa każdego ucznia, członka wspólnoty Janowej ${ }^{\text {`` }}$ Na podstawie tekstów Filona H. Weiss wyciąga wniosek, iż w helleńskiej synagodze I w. po Chr. obmycie nóg było widziane jako przygotowanie do spotkania z Bogiem, stąd gest Jezusa także wyraża przygotowanie uczniów do takiego spotkania ${ }^{77}$. Odwołując się do żydowskiego zwyczaju mycia nóg jako znaku powitania i gościnności, A.J. Hultgren interpretuje gest Jezusa jako symboliczny akt eschatologicznej gościnności. Wyjaśnienie to nie jest oryginalne, gdyż już Ambroży z Mediolanu (Comm. in Luc. 6,67) mówi o przyjęciu uczniów do domu Jezusa poprzez gest umycia ich nóg. Zdaniem Hultgrena Jezus opuszczający ten świat i zmierzający do Ojca $(13,1.3)$ wykonuje gest powitania i gościnności, przyjmując uczniów do miejsca, do którego zmierza, do domu Ojca $(14,2)$. Jezus jest tutaj sługą bogatego i hojnego gospodarza, Boga, który wita uczniów w domu Ojca, aby w nim odpoczęli i przebywali. Uczniowie zrozumieją sens tego gestu dopiero w momencie uwielbienia Jezusa $(13,7)^{78}$. W podobnym duchu M.L. Coloe interpretuje gest Jezusa nie tyle jako gest gościnności, ile jako proleptyczną czynność powitania w domostwie Boga (household of God) $(14,2)^{79}$. Biorąc pod uwagę funkcjonalny status niewolnika w starożytności, który często reprezentował swego pana (np. podpisując kontrakt w imieniu swego właściciela ${ }^{80}$ ), Jezus występuje tutaj w roli przedstawiciela i pośrednika (broker) Boga Ojca. Również odwołując się do kulturowego znaczenia gestu umycia nóg jako znaku powitania, M. Pesce i A. Destro twierdzą, iż akt Jezusa był dla uczniów rytem wejścia do wspólnoty, utworzenia grupy uczniów, stworzenia nowego typu wspólnoty przyjaciół opartej

vue. Actes du III colleque international du Réseau de recherche en narrativité biblique. Paris, 8-10 juin 2006 (red. D. Marguerat) (Lectio Divina; Paris: Cerf 2007) 325-338.

76 J.A.T. Robinson, „The Significance of the Foot-Washing”, Neotestamentica et Patristica. Freundengabe Oscar Cullmann (red. W.C. van Unnik) (NT.S 6; Leiden: Brill 1962) 144-147; H. Weiss, „Foot Washing in the Johannine Community”, NT 21 (1979) 298-325, esp. 320: „the Johannine community performed the act as preparation for martyrdom that would issue in a vision of God." Weiss w istocie widzi dwa zbieżne znaczenia gestu: (1) przygotowanie do męczeństwa, które będzie skutkować (2) doświadczeniem obecności Boga.

77 Weiss, „Foot Washing”, 304. Filon Aleksandryjski nadał starotestamentalnemu rytowi kapłańskiego obmycia nóg znaczenie moralne: czyste nogi są symbolem ( $\sigma 0 ́ \mu \beta o \lambda o v)$ bezgrzesznego życia, zmierzania drogą cnoty, a nie drogą wad (Mos. 2,138; cf. Q. Gen. 4,60). Jednocześnie czyste nogi są dla Filona znakiem trwania w obecności Boga (zob. Q. Gen. 4,5; Q. Exod. 1,2; Spec. Leg. 1,38,206).

78 A.J. Hultgren, „The Johannine Footwashing (13.1-11) as Symbol of Eschatological Hospitality”, NTS 28 (1982) 539-546, zwłaszcza 542. Autor ten (s. 544) mówi także o symbolizmie chrzcielnym perykopy J 13,1-11: „there can be little doubt but what 13,1-11 has baptismal overtones”. Chrześcijanin (członek Wspólnoty Janowej) doświadcza Bożej gościnności poprzez chrzest.

79 Coloe, „Welcome into the Household of God”, 400-415.

80 Por. J.F. Gardner - T. Wiedemann, The Roman Household. A Sourcebook (London: Routledge 1991) 74-75. 
na służbie i miłości ${ }^{81}$. W tym duchu podąża także interpretacja C. Niemanda, który tłumaczy gest umycia nóg jako praktykę wspólnoty Janowej, witającej i przyjmującej w ten sposób do swego grona uczniów Jana Chrzciciela, którzy przyjęli już wcześniej chrzest (Janowy) ${ }^{82}$. Dla J. Massyngbaerde Ford akt Jezusa jest posługą przyjaciela wobec przyjaciół. Gest ten kreuje lub pogłębia więź wzajemnej przyjaźni między Jezusem i Jego uczniami, profetycznie wskazując na najwyższy znak przyjaźni, jakim jest oddanie życia za przyjaciela (por. 15,13-15). W istocie Jezus (będąc posłanym przez Ojca) wprowadza uczniów W więź przyjaźni z samym Bogiem ${ }^{83}$. C. Bennema interpretuje J 13,1-20 poprzez pryzmat starożytnej teorii mimesis, w świetle której wierzący jest wezwany do naśladowania czynu Jezusa razem z motywem stojącym za zachowaniem Jezusa. Motywem tym jest miłość aż po oddanie życia ${ }^{84}$.

Wymieniając przykładowe wyjaśnienia symboliczne, należy także wspomnieć o interpretacjach mniej przekonujących. Dla przykładu R. Eisler odwołuje się W swej egzegezie J 13,1-20 do rzeczywistości zaślubin. W opinii niemieckiego egzegety umycie nóg jest znakiem mistycznej wspólnoty z Jezusem ${ }^{85}$. Interpretacja ta odwołuje się do zwyczaju zarówno pogańskiego (Servius, Aen. 4,167), jak i żydowskiego, w którym ceremonia małżeństwa była poprzedzona kąpielą i umyciem nóg. W Biblii hebrajskiej wyrażenie „umyć sobie nogi” może być także rozumiane jako eufemizm i oznaczać współżycie seksualne (2 Sm 11,8). R. Eisler wskazuje także na kabalistyczny traktat Raaiah Mehemnah, mówiący o mistycznych zaślubinach Izraela (Małżonki) z Bogiem (Małżonkiem), mających miejsce w czasie Paschy (zob. J 13,1), w momencie rytualnej czystości małżonki (zob. 13,10). Bez wątpienia symbolika małżeńska jest obecna w czwartej Ewangelii $^{86}$, jednak gest obmycia nóg wydaje się jedynie jej dalekim echem.

81 Destro - Pesce, „La lavanda dei piedi nel Vangelo di Giovanni: un rito di inversione”, 9-27. Por. także Pesce, „Il lavaggio dei piedi (Gv 13,1-20)”, 240-241.

82 C. Niemand, Die Fusswaschungserzählung des Johannesevangeliums. Untersuchungen zu ihrer Entstehung und Überlieferung im Urchristentum (Studia Anselmiana 114; Roma: Pontificio Ateneo S. Anselmo 1993) 404-411.

83 Klucz przyjaźni jest niezwykle przekonującym kontekstem dla wyjaśniania gestu Jezusa, gdyż zarówno w świecie grecko-rzymskim, jak i żydowskim przyjaźń była niezwykle cenionym ideałem, a temat ten jest obecny w Janowym opisie Ostatniej Wieczerzy (15,13-15). W starożytności przyjaciele traktowali siebie jako równych (zob. 15,15). Początek przyjaźni był nierzadko sformalizowany i zrytualizowany. Znakiem przyjaźni było wyświadczanie sobie różnych przysług, pełnienie dobrych czynów, z których największym było bez wątpienia oddanie życia za przyjaciela (zob. 15,13). Więcej J. Massyngbaerde Ford, Redeemer - Friend and Mother. Salvation in Antiquity and in the Gospel of John (Minneapolis, MN: Fortress 1997) 136-146.

84 C. Bennema, „Mimesis in John 13: Cloning or Creative Articulation?”, NT 56 (2014) 273: „The point of the mimesis is that believers, in imitation of their master, should love one another sacrificially and limitlessly, to the extent that it may ultimately be demonstrable in death".

85 R. Eisler, ,Zur Fusswaschung am Tage vor dem Pessah (Ev. Joh. 13,2-16)”, ZNW 14 (1913) 268-271.

86 Zob. C. Rusconi, Le nozze dell'Agnello. La metafora delle nozze in San Giovanni (Scienze Religiose Gregorio da Rimini; Rimini: Pazzini 2008); A. Kubiś, „Radość Przyjaciela Oblubieńca 
Odwołując się również do $2 \mathrm{Sm} 11,8$ oraz dodając jako kontekst interpretacyjny tekst Ap 14,1-5, J. Swetnam wyjaśnia gest Jezusa w J 13,1-20 jako przygotowanie wojowników do świętej wojny miłości (a Holy War of love). Ta niezwykle oryginalna propozycja nie zyskała jednak uznania późniejszych komentatorów. Jedynie J.H. Neyrey zauważył, iż Janowe powiązanie Jezusowego umycia nóg ze śmiercią odpowiada idei bycia w stanie rytualnej czystości w obliczu śmiertelnego niebezpieczeństwa obecnego $\mathrm{w}$ czasie wojny ${ }^{87}$. Główną słabością hipotezy Swetnama jest bazowanie na niepotwierdzonym w źródłach (biblijnych i pozabiblijnych) zwyczaju obmywania nóg przed „świętą wojną” jako znaku czystości rytualnej koniecznej do prowadzenia wojen przez starotestamentalnych Izraelitów. Kolejną słabością jest brak wyraźnych aluzji do tematyki „świętej wojny" w J 13 i bezpośrednim kontekście literackim. Wskazywany przez Swetnama uroczysty wjazd Jezusa do Jerozolimy jest w istocie antywojenny, gdyż Zachariaszowy mesjański król niszczy wszelką broń w Efraimie i Judzie, zwiastując pokój (Za 9,9-10). Pozostałe aluzje wskazywane przez rzymskiego biblistę albo mogą mieć status odległego echa, albo są niezwykle dyskusyjne ${ }^{88}$.

\section{Interpretacje sakramentalne}

Z punktu widzenia historii egzegezy w mówieniu o sakramentalnej interpretacji Janowego gestu umycia nóg obecne są dwa podejścia. (1) W pierwszym z nich tłumaczono ryt umycia stóp jako udzielanie jednego z sakramentów. W istocie w pewnych okresach pojawiało się przekonanie, iż gest ten nie tylko był udzieleniem sakramentu chrztu czy sakramentu pokuty, ale umycie nóg samo w sobie jest kolejnym, innym sakramentem (np. u anabaptystów). Pewną mutacją tego poglądu było przekonanie, potępione na synodzie w Elwirze (ok. 306 r.), iż ryt umycia nóg, nie będąc sakramentem, ma skutki sakramentalne. Otóż kanon 48. tego synodu zabrania mycia nóg nowoochrzczonym przez kapłanów czy innych duchownych. Kanon ten poświadcza istnienie praktyki łączenia chrztu

z powodu głosu Oblubieńca w J 3,29", Radość Ewangelii. Biblijne źródła chrześcijańskiej radości (red. A. Zawadzki) (Analecta Biblica Lublinensia 13; Lublin: Wydawnictwo KUL 2016) 163-192.

87 J.H. Neyrey, The Gospel of John (NCBC; Cambridge: Cambridge University Press 2007) 230.

88 J. Swetnam zaprezentował swą interpretację w ramach recenzji książki G. Richtera (Die Fusswaschung im Johannesevangelium. Geschichte ihrer Deutung) opublikowanej na łamach kwartalnika Biblica 49/3 (1968) 439-444. Sam Swetnam był świadom wysokiej hipotetyczności swej propozycji interpretacyjnej, gdy stwierdził (Ibidem, 444): ,if von Rad's theory of a Holy War is correct, and if there was a ceremony involving a washing of the feet to symbolize in some way ritual purity for the warrior, and if that symbolism was still appreciated and understood in the time of Christ, and if the allusions in the Fourth Gospel warrant the supposition of the Holy War imagery in Jn 13, then the suggestion advanced here has merit". 
$\mathrm{z}$ umyciem nóg. (2) W drugim podejściu interpretacyjnym identyfikowano w opisie Janowym jedynie nawiązania, aluzje czy echa do sakramentu czy sakramentów z przekonaniem, iż sam ryt obmycia nóg w swoim dosłownym i historycznym wymiarze miał sens niesakramentalny ${ }^{89}$. Oba powyższe podejścia - ryt jest opisem sakramentu oraz ryt nie jest sakramentem, ale opis ma wątki sakramentalne - są obecne wśród komentatorów. Przy tym podejście pierwsze było dominujące w starożytności, podejście drugie natomiast jest praktycznie jedynym, jakie spotyka się wśród współczesnych autorów dopuszczających możliwość interpretacji sakramentalnej.

Oczywiście nie wszyscy komentatorzy widzą element sakramentalny w J 13,1-20. R. Kysar, odrzucając interpretacje sakramentalne, twierdzi, iż wśród pierwszych chrześcijan sakramenty nie były jeszcze tak popularne, aby każde nowotestamentalne odniesienie do standardowej sakramentalnej terminologii (np. w przypadku chrztu do terminów „woda” oraz „zanurzenie”, „obmycie”) traktować jako niezawodne odniesienie do sakramentu ${ }^{90}$. Zastrzeżenie R. Kysara nie jest do końca uprawnione w przypadku chrztu, gdyż sakrament ten występuje explicite w tekstach NT (Mt 28,19; Dz 2,38; 8,12-13; 10,47; Rz 6,3-4; por. Mk 16,16). Podobnie rzecz się ma z Eucharystią (1 Kor 11,24; Łk 22,19; Mk 14,22-25; Mt 26,26-29). Teksty te pokazują ważność, a nawet centralną rolę sakramentu chrztu i Eucharystii w życiu rodzących się pierwotnych wspólnot chrześcijańskich. Teksty nowotestamentowe mówiące o tych sakramentach powstały przed lub w czasie komponowania czwartej Ewangelii. Wobec powyższego aluzje

89 Należy tutaj powtórzyć za R.E. Brownem (John, II, 559), iż w Ewangelii Jana symbolika sakramentalna jest na drugim planie (,a secondary level”), reinterpretując czyny i słowa Jezusa, które miały swoje pierwotne znaczenie ściśle związane z Jego posługą. Współcześni komentatorzy zatem, jeśli już odwołują się do interpretacji sakramentalnych, wskazują na ich wtórny charakter. R.E. Brown (Introduction, 230) zauważył również, iż niemal wszystkie odniesienia sakramentalne w czwartej Ewangelii funkcjonują na zasadzie symbolizmu. Fakt ten ma źródło w wielkiej wrażliwości pierwotnego Kościoła na zjawisko typologii. NT zawiera przykłady egzegez typologicznych (zasada: ST wypełnia się w NT). Z tego powodu, na zasadzie typologii, wiele czynów i słów Jezusa widziano jako zapowiedzi (typy) sakramentów Kościoła.

90 R. Kysar, The Fourth Evangelist and His Gospel. The Examination of Contemporary Scholarship (Minneapolis, MN: Fortress 1975) 256. Opinia Kysara powiela mające już długą tradycję przekonanie, iż Ewangelia Jana jest zupełnie niezainteresowana sakramentami i można ją określić jako wręcz , anty-sakramentalną”. Pogląd ten najmocniej został wyłożony w H. Odeberg, The Fourth Gospel. Interpreted in Relation to Contemporaneous Religious Currents in Palestine and the Hellenistic-Oriental World (Uppsala - Stockholm: Almqvist \& Wiksells Boktryckeri 1929), a później w komentarzu R. Bultmanna z 1941 r., który twierdził, iż pierwotna wersja Ewangelii była antysakramentalna, ale „Kościelny Redaktor” dodał do niej odniesienia do chrztu i Eucharystii $(3,6 ; 6,51-58 ; 19,34)$ w celu dostosowania się do sakramentalnych praktyk „większego (czyli powszechnego) Kościoła”. Teoria Bultmanna nie jest przekonująca, gdyż nawet jeśli jakimś sposobem ,udowodnimy” redakcyjny charakter sakramentalnych fragmentów tekstu, nie będzie to świadczyć o ,antysakramentalności” wcześniejszego autora, ale o innym stopniu sakramentalności danego etapu redakcji tekstu. 
chrzcielne i eucharystyczne w czwartej Ewangelii, pisanej w tymże rodzącym się Kościele, są jak najbardziej prawdopodobne. Trudno także z przekonaniem argumentować, że nowotestamentowe teksty mówiące o odpuszczeniu grzechów (J 20,22-23) czy wyznawaniu grzechów (Jk 5,16; $1 \mathrm{~J}$ 1,9) nie pociągały za sobą aktów (tj. zewnętrznych znaków, jak choćby ustne wyznanie grzechu), stanowiących pierwowzór sakramentu. Sakrament w istocie rozumiany jest bowiem jako zewnętrzny (materialny) znak powiązany z udzieleniem przez Boga (niewidzialnej) łaski.

G. Richter zamyka swoje monograficzne studium konkluzją, iż sakramentalny symbolizm nie był celem, dla którego ewangelista pisał swoje dzieło. Celem tym była wiara w Jezusa jako Mesjasza $(20,31)^{91}$. Tak zdefiniowany cel nie wklucza jednak stwierdzenia, iż ewangelista prowadzi do wiary w Mesjasza, który odpuszcza grzechy - twierdzenie niezwykle mocno obecne w czwartej Ewangelii (zob. 1,29; 8,32-36; 20,23). Dominujące dziś symboliczne wyjaśnienie gestu Jezusa jako profetycznego znaku Jego odkupieńczej śmierci w istocie nie przeczy interpretacji chrzcielnej i pokutnej, ale się z nią pokrywa. W świetle teologii Janowej oczyszczenie wierzącego z grzechu następuje przez krew Jezusa (1 J 1,7; por. Hbr 9,14). Inne teksty NT ukazują, iż oczyszczenie to jest udzielane wierzącemu poprzez chrzest (zob. Ef 5,26; Hbr 10,22).

Zanim zostaną przedstawione argumenty za możliwością pokutnej interpretacji gestu Jezusa, najpierw będą zaprezentowane argumenty komentatorów widzących w Janowym opisie obmycia uczniom stóp odwołania do innych sakramentów. W J 13,1-20 widzi się bowiem nawiązania do chrztu, Eucharystii, kapłaństwa oraz nieznanego sakramentu.

\subsection{Chrzest}

Do czasu prac G. Richtera w latach 60. XX w. odniesienie do sakramentu chrztu było dominującym sposobem wyjaśniania przez egzegetów zachodnich perykopy o umyciu uczniom nóg przez Jezusa. Dla niektórych komentatorów gest obmycia nóg nie tylko przywoływał sakrament chrztu, ale był wręcz opisem ustanowienia tegoż sakramentu ${ }^{92}$ czy nawet momentem chrztu apostołów ${ }^{93}$. Mimo

91 Richter, Die Fusswaschung, 298.

92 J.N. Sanders, A Commentary on the Gospel of St. John (red. B.A. Mastin) (London: Adam \& Charles Black 1968).

93 W. Bauer, Das Johannesevangelium erklärt (Handbuch zum Neuen Testament 6; Tübingen: Mohr Siebeck 1912. $\left.{ }^{3} 1933\right)$ 167. Tradycja mówiąca, iż w czasie Ostatniej Wieczerzy Jezus ochrzcił Piotra, który następnie ochrzcił Andrzeja, ten z kolei Jakuba i Jana, sięga Klemensa Aleksandryjskiego (Hypotyp. V,6; GCS 17,196). Zob. H.A. Echle, „The Baptism of the Apostles. 
swej popularności w czasach współczesnych, interpretacja chrzcielna samego gestu umycia nóg nie jest zbyt mocno poświadczona w dziełach patrystycznych. Wśród łacińskich ojców Kościoła rozpowszechnione było bowiem nieco inne wyjaśnienie, a mianowicie w zdaniu „Wykąpany (ó $\lambda \varepsilon \lambda o v \mu \varepsilon ́ v o \varsigma)$ potrzebuje tylko nogi sobie umyć (ví $\alpha \sigma \theta \alpha$ l), bo cały jest czysty" $(13,10)$ widziano odniesienie do dwóch obmyć. Pierwsze, do którego nawiązuje imiesłów ó $\lambda \varepsilon \lambda o v \mu \varepsilon ́ v o \varsigma$, starożytni autorzy odnosili do chrztu, który uczniowie mieli przyjąć znaczenie wcześniej, np. od Jana Chrzciciela lub nawet od samego Jezusa ${ }^{94}$. Drugie, o którym mówi czasownik ví $\alpha \sigma \theta \alpha$ i który określa umycie stóp dokonane przez Jezusa, było widziane jako znak przebaczenia grzechów popełnionych po chrzcie ${ }^{95}$. Co ciekawe, Ambroży interpretował cały wiersz 13,10 wyłącznie przez pryzmat chrztu, widząc w dwóch wzmiankach o umyciu dwa rodzaje grzechów usuwanych przez chrzest: ó $\lambda \varepsilon \lambda o v \mu \varepsilon ́ v o \varsigma$ odnosi się do grzechów osobistych, a ví $\alpha \sigma \theta \alpha$ do grzechu pierworodnego ${ }^{96}$. Wyjaśnienie to nie znalazło jednak uznania wśród komentatorów późniejszych wieków. Interpretacja widząca w samym geście umycia nóg znak oczyszczenia chrzcielnego, prócz powyższego ujęcia Ambrożego miałaby znajdować się tylko u niewielkiej liczby wczesnych autorów (Tertulian, Cyprian, Afrahat, Cyryl Aleksandryjski), jednak i w ich przypadku rodzą się niejednokrotnie wątpliwości, czy istotnie rozumieli

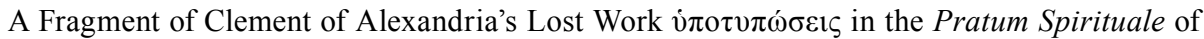
John Moschus", Traditio 3 (1945) 365-368.

94 Tertulian (De baptismo, 12,3; CCL I, 287) łączy J 13,10 z chrztem apostołów otrzymanym od Jana Chrzciciela. Augustyn (Ep. 44,5,10) przywoływał J 13,10 jako dowód na to, iż apostołowie zostali ochrzczeni przez Jezusa, a nie przez Jana Chrzciciela. Glossa ordinaria (PL 114,405) stwierdza, iż J 13,10 jest dowodem na ochrzczenie apostołów, jednak bez podania informacji, gdzie i kiedy to nastąpiło. W sposób mistrzowski powyższą kwestię analizuje w swym komentarzu do J 13,10 Tomasz z Akwinu: „Niektórzy [...] mówią, że [uczniowie] byli ochrzczeni jedynie chrztem Janowym, to jednak nie wydaje się być prawdziwe. W ten sposób bowiem nie byliby wykąpani, bowiem chrzest Jana nie oczyszczał wewnętrznie z grzechu. I dlatego, idąc za Augustynem, należy powiedzieć, że zostali ochrzczeni chrztem Chrystusa. Jeśli jednak postawisz zarzut, że Chrystus nie chrzcił, lecz Jego uczniowie, jak powiedziano wcześniej w J 4,2, powiadam, że nie chrzcił tłumów, jednak ochrzcił swoich uczniów, którzy byli mu bliscy, oraz domowników". Za: Święty Tomasz z Akwinu, Komentarz, 824. Zob. także Optat z Mileve, De schismate donatistarum 4,4 (PL 11,1031) oraz 5,3 (PL 11,1049-1050).

95 Doskonałym przykładem takiej interpretacji jest list Pacjana z Barcelony (Ep. 3,10; PL 13,1070), w którym cytuje J 13,10, odpierając herezję nowacjan wykluczających możliwość pokuty po chrzcie. W takim samym celu użył Janowego tekstu również Hieronim (Adversus Jovinianum 2,3; PL 23,297), a wcześniej Optat z Mileve (De schismate donatistarum 4,4; PL 11,1031) i Pseudo-Cyprian (Coena, PL 4,925-931). Stałe używanie tego wersetu przez ojców łacińskich jako argumentu przeciw powtarzaniu chrztu również poświadcza powyższą interpretację, w której obmycie nóg było rozumiane nie jako chrzest, ale sakrament pokuty. Szczegółowe omówienie interpretacji patrystycznych J 13,10 przedstawia N.M. Haring, „Historical Notes on the Interpretation of John 13:10", CBQ 13 (1951) 355-380.

96 De mysteriis 6,32 (PL 16,398-399; SC 25,117-118). 
gest Jezusa jako symbol chrztu ${ }^{97}$. Poniżej przedstawimy argumenty wysuwane za poparciem interpretacji chrzcielnej J 13,1-20. Podstawą analizy jest finalna forma tekstu Janowego, w tym tzw. dłuższa wersja $\mathrm{J}$ 13,10, zawierająca słowa

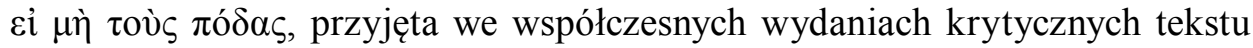
czwartej Ewangelii (Nestle-Aland, wyd. 28). Wers ten jest kluczowy z punktu widzenia interpretacji chrzcielnej oraz pokutnej ${ }^{98}$.

Można wskazać trzy rodzaje argumentów za chrzcielną interpretacją J 13,1-20. Wpierw te, które w ślad za starą tradycją poświadczoną przez ojców łacińskich

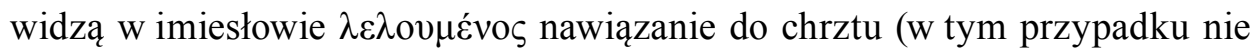
chodzi o gest obmycia nóg) ${ }^{99}$. Kolejne to argumenty sugerujące nawiązanie do chrztu w samym geście obmycia nóg. Na końcu przytoczymy argumenty, które wspierają interpretację chrzcielną w obu powyżej wspomnianych obmyciach.

\section{Aluzja do chrztu, którym nie jest umycie nóg}

Istnieją cztery podstawowe argumenty za widzeniem w ogólnym obmyciu, o którym jest mowa w 13,10, nawiązania do sakramentu chrztu. (1) Z reguły głównym argumentem za interpretacją chrzcielną Janowej perykopy o umyciu

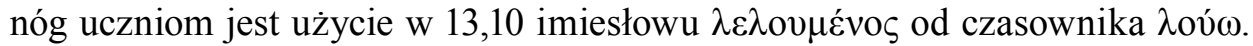
Czasownik ten można przetłumaczyć jako „kąpać (się)” lub „myć (się)”. Ten właśnie termin miałby odnosić się do chrztu. Przekonanie o tym bazuje na obserwacji, iż w NT jest on synonimem czasownika $\beta \alpha \pi \tau i \zeta \omega$, który oznacza ,zanurzanie" i „chrzczenie”. Otóż, czasownik $\lambda$ ov́ $\omega$ odnosi się do chrztu w sposób ewidentny w Hbr 10,22. Nadto dwa terminy pochodne od $\lambda$ ov́ $\omega$ również użyte

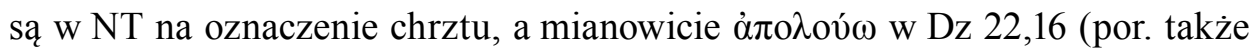

97 Przykładem jest Tertualian, który w swoim dziele De baptismo $(12,3$; SCh 35,83$)$ twierdzi, iż obmycie wrażone przez ó $\lambda \varepsilon \lambda o v \mu \varepsilon ́ v o \varsigma$ w 13,10 odnosi się do chrztu (kontekst wskazuje na chrzest Janowy), jakiego mieli doświadczyć apostołowie. W tym samym dziele $(9,4$; SCh 35,79$)$ pisze o nowotestamentowych typach chrztu, zaliczając do nich udzielenie wody przez Chrystusa swym uczniom (aquam discentibus ministrat). Nie wiemy jednak dokładnie, czy Tertulian ma na myśli umycie uczniom nóg (J 13,5.14), czy obietnicę dania wody uczniom $(4,14)$. Cyprian nigdzie w swych działach nie cytuje J 13,10, ale robi doń jedynie aluzję w $D e$ buono patientiae 6. Cyryl interpretuje gest Jezusa jako przykład pokory, wspomina jednak o wejściu do królestwa niebieskiego poprzez obmycie z grzechów, które następuje przez miłość oraz uświęcenie w Duchu poprzez chrzest (In Joannem 9). Powyższe twierdzenie nie dowodzi jednak bezsprzecznie, iż Cyryl wiązał chrzest z umyciem nóg. Szerokie omówienie tekstów patrystycznych interpretujących J 13,1-20 w P.F. Beatrice, La lavanda dei piedi. Contributo alla storia della antiche liturgie cristiane (Bibliotheca Ephemerides Liturgicae Subsidia 28; Roma: C.L.V. Edizioni litrugiche 1983) oraz C. Egasse, Le lavement des pieds. Recherche sur une pratique négligée (Christianismes Antiques; Genève: Labor et Fides 2015).

98 Obszerne studia poświęcone oryginalnej wersji tekstu greckiego wiersza 13,10 przygotowali J.C. Thomas, „A Note on the Text of John 13:10”, NT 291 (1987) 46-52 oraz J.C. O’Neil, ,John 13:10 Again", RB 101 (1994) 67-74.

99 Dla przykładu Augustyn, Tractatus in Johannem 56,2-4 (PL 35,1788). 


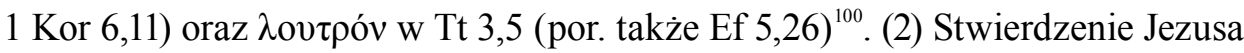
o wykąpanym (rozumianym jako ochrzczony), który cały jest czysty $(13,10)$,

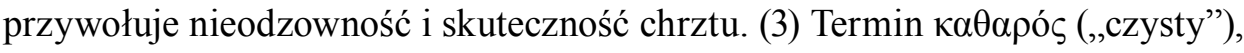

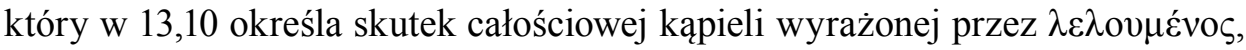
łączony jest w NT z chrztem (por. Tt 2,14; Hbr 1,3; 9,14.22; 10,2; 12,24; 1 P 1,2; 2 P 1,9$)^{101}$. (4) Interpretacja taka jest dodatkowo przekonująca w świetle wczesnochrześcijańskiej praktyki chrzczenia przez całkowite zanurzenie.

Według O. Cullmanna tekst J 13,1-20 mógł być polemiką skierowaną przeciw praktyce ponownego chrztu ${ }^{102}$. Zwyczaj ponownego chrztu był w istocie niezwykle palącym problemem Kościoła starożytnego. Dla przykładu, sekta hemerobaptystów praktykowała nawet codzienny chrzest. W efekcie wielu autorów starożytnych i średniowiecznych przywoływało J 13,10 jako argument za odrzuceniem praktyki ponownego chrztu. W tej interpretacji, słowa „Wyką-

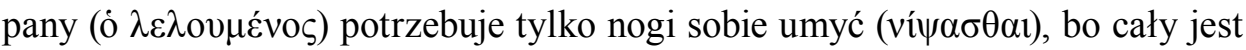
czysty" $(13,10)$ wyrażają brak konieczności drugiego chrztu (drugiej kąpieli) po jego przyjęciu w przeszłości (ỏ $\lambda \varepsilon \lambda o v \mu \varepsilon ́ v o \varsigma)$. Nawet jeśli ochrzczony zaczął grzeszyć po chrzcie, nie powinno się udzielać mu chrztu po raz drugi. Tak jak śmierć Jezusa nie może być powtórzona, podobnie nie może być zwielokrotniany chrzest (por. Hbr 6,6).

\section{Aluzja do chrztu, którym jest umycie nóg}

Szukając znaczenia chrzcielnego w samym geście umycia nóg, można przytoczyć kilka argumentów potwierdzających taką interpretację tej czynności Jezusa. (1) Przyjmując za większością egzegetów podstawowy sens gestu Jezusa jako zapowiedzi Jego odkupieńczej śmierci dającej odpuszczenie grzechów, w sposób naturalny nasuwa się połączenie między zbawczą śmiercią Jezusa i chrztem. Otóż, chrzest jest sposobem, dzięki któremu uczeń Jezusa, w sposób oczywisty i naturalny, cieszy się skutkami odkupieńczej śmierci Jezusa ${ }^{103}$. (2) Według

100 Fakt, iż czasowniki $\lambda$ ov́ $\omega$ oraz ví $\pi \omega$ są synonimami, nie podważa tego argumentu.

101 Richter (Die Fusswaschung, 295-296) uważa, iż odwołanie do „oczyszczenia” nie jest argumentem za symboliką chrzcielną, gdyż w pismach Janowych oczyszczenie nie dokonuje się za sprawą wody, ale krwi Jezusa (zob. 1 J 1,7; 3,5; 4,10; Ap 1,5; 7,14; 22,14). Zarzut ten nie jest do końca przekonujący, gdyż w świetle J 19,34 oczyszczenie z grzechów dokonane krwią Jezusa jest doświadczane przez wierzącego poprzez wody chrztu.

102 O. Cullmann, La foi et le culte de l'Église primitive (Bibliothèque Théologique; Neuchatel: Delachaux et Niestlé 1963) 198.

103 R.E. Brown, recenzja G. Richter, Die Fusswaschung im Johannesevangelium. Geschichte ihrer Deutung (Biblische Untersuchungen 1; Regensburg: Pustet 1967), Theological Studies 30 (1969) 121: „If the foot washing symbolized Jesus' salvific death, would not reflection on this symbolism have quickly evoked baptism, the washing by which Christians were brought into contact with Jesus' salvific death and made sharers in His heritage?" 
J 13,8 Piotr musi mieć obmyte nogi, inaczej bowiem nie będzie miał „udziału”

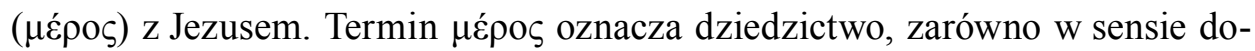
czesnym (terytorium), jak i eschatologicznym (zbawienie). Synonim terminu $\mu \varepsilon \dot{\rho} \rho \varsigma$, jakim jest $\kappa \lambda \eta \rho o v o \mu i ́ \alpha$, występuje w NT w kontekstach odnoszących

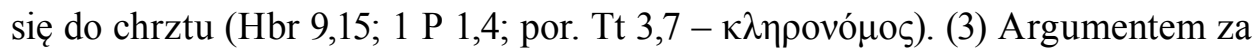
interpretacją chrzcielną gestu umycia nóg jest emfatyczny język, jakim Jezus zwraca się do Piotra: „Jeśli cię nie umyję, nie będziesz miał udziału ze Mną” $(13,8)$. Zdanie to wskazuje na nieodzowność obmycia stóp, nieodzowność zaś jest cechą chrztu. (4) Zdaniem P. Grelota Janowe użycie czasownika ví $\pi \omega$ (,umyć”) w narracji o uzdrowieniu niewidomego od urodzenia (9,7bis.11bis.15) jest ewidentnym nawiązaniem do chrztu, gdyż przywrócenie wzroku następuje za sprawą obmycia wodą. Przywrócenie wzroku w tekście J 9 ma oczywiste znaczenie symboliczne, które można określić jako oświecenie poprzez wiarę. Także obmycie wodą, które w sposób praktyczny prowadzi do tego oświecenia, może mieć znaczenie symboliczne, a mianowicie może oznaczać chrzest ${ }^{104}$. Czasownik ví $\tau \omega$, mający zatem konotację chrzcielną w J 9, obecny jest także w J 13,5.6.8bis.10.12.14bis, gdzie określa umycie nóg. Co istotne, termin ten występuje tylko w tych dwóch perykopach Janowych.

H. von Campenhausen zwrócił uwagę na słowa Piotra, który prosi o umycie głowy i rąk $(13,9)$. W jego mniemaniu jest to nawiązanie do praktyki kościelnej, w której chrzczono przez polanie wodą, a kandydat stał po kostki w wodzie. Chrzest Piotra i innych apostołów miałby nastąpić przez umycie im nóg. Piotr, chcąc zanurzenia całego ciała, wyraża opinię uczniów Jana Chrzciciela, pragnących chrztu wyłącznie przez zanurzenie. Tekst Janowy, ukazujący Jezusa chrzczącego przez obmycie stóp, byłby zatem polemiką z praktyką kościelną chrzczenia poprzez całkowite zanurzenie ${ }^{105}$. Słabością tej interpretacji jest brak wyjaśnienia, do czego może się odnosić określenie „wykąpany” (ỏ $\lambda \varepsilon \lambda o v \mu \varepsilon ́ v o \varsigma$ ) w 13,10. Jeśli $\lambda \varepsilon \lambda o v \mu \varepsilon ́ v o \varsigma$ odnosiłoby się do chrztu przez zanurzenie, wówczas tekst sugerowałby konieczność ponownego chrztu w przypadku Piotra przez polanie wodą (w tym przypadku nóg); sugestia trudna do przyjęcia. Jak za-

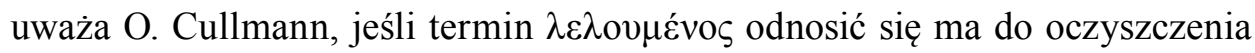
przez słowo (por. 15,3), wówczas problem polemiki pomiędzy „,chrztem przez zanurzenie” a „chrztem przez polanie” wodą traci swe podstawy w tekście ${ }^{106}$.

104 Grelot, „L'interprétation pénitentielle”, 86: „N'en concluons pas que le verbe ví $\tau \omega$ s'emploiera exclusivement pour désigner le baptême; mais il connote du moins une certaine purification de l'homme qui s'opère grâce au lavage du baptême".

105 H. von Campenhausen, „Zur Auslegung von Joh 13,6-10”, ZNW 33 (1934) 259-271, zwł. 261270.

106 Cullmann, La foi et le culte de l'Église primitive, 198, przyp. 3. 


\section{Argumenty wspierające zarówno pierwsze, jak i drugie rozwiązanie}

Po pierwsze, obecność nawiązań do chrztu w innych tekstach czwartej Ewangelii ma niebagatelne znaczenie w ukazaniu prawdopodobieństwa odniesienia do chrztu w Janowym opisie umycia uczniom nóg. W rozmowie Jezusa z Nikodemem temat chrztu jest bodajże najlepiej widoczny w całej czwartej Ewangelii ${ }^{107}$. Australijski egzegeta J.F. Moloney przedstawił imponujący wykaz tekstów z Ewangelii Janowej, w których na przestrzeni wieków egzegeci doszukiwali się mniej lub bardziej uzasadnionych odniesień do chrztu. Prócz umycia nóg i powyżej wzmiankowanego dialogu z Nikodemem wymienia jeszcze: chrzest Jezusa, wesele w Kanie, oczyszczenie świątyni, rozmowa z Samarytanką, uzdrowienie paralityka przy sadzawce Betesda, chodzenie po wodzie, słowa Jezusa o wodzie wypływającej z Jego wnętrza $(7,38)$, uzdrowienie niewidomego od urodzenia, mowa o Dobrym Pasterzu, wskrzeszenie Łazarza, woda wypływająca z przebitego boku Jezusa, cudowny połów ryb w rozdziale $21 .{ }^{108}$ Oczywiście, jak słusznie podkreśla J.F. Moloney, fakt interpretowania danego tekstu na sposób sakramentalny (tutaj chrzcielny) nie oznacza, iż rzeczywiście tekst ten miał znaczenie sakramentalne dla piszących Ewangelię i jej pierwotnych słuchaczy ${ }^{109}$.

Po drugie, J.F. Moloney podał cztery kryteria, które jego zdaniem, są pomocne w identyfikacji sakramentalnego znaczenia danego tekstu w czwartej Ewangelii. Pierwszym kryterium są elementy sugerujące interpretację chrzcielną obecne w samym tekście Janowym. Wskazaliśmy je powyżej. Drugim kryterium jest użycie danego tekstu w liturgii, literaturze i sztuce wczesnego Kościoła. Odnośnie do tego kryterium, znacząca część tradycji patrystycznej poświadcza chrzcielną interpretację J 13,1-20 i jej użycie w rytach chrzcielnych (np. Hiszpania oraz Mediolan). Pozostałe dwa kryteria są mniej użyteczne w analizie tekstu J 13,1-20 ${ }^{110}$.

107 W dialogu między Jezusem i Nikodemem nie pojawia się oczywiście słowo chrzest, ale połączenie tematu wody i ducha sugeruje obecność tematyki chrztu. Jan stwierdza, iż aby wejść do królestwa Bożego należy się narodzić z wody i ducha $(3,5)$. Połączenie rzeczywistości wody i ducha czy konkretnie chrztu (jako obmycia) i Ducha spotykamy w 1 Kor 6,11 i 12,13, gdzie Paweł mówi o chrzcie. Spotykamy je także w Dziejach Apostolskich $(2,38 ; 10,44-48 ; 19,1-6)$. Zob. I. de la Potterie, , «To be Born Again of Water and the Spirit» - The Baptismal Text of John 3,5", The Christian Lives by the Spirit (Staten Island, NY: Alba House 1971) 1-36; P.R. Tragan, „Battesimo e fede cristologica nel dialogo tra Gesù e Nicodemo (Gv 3,1-21)”, Fede e sacramenti negli scritti giovannei. Atti del VI convegno di teologia sacramentaria. Roma, 23-25 maggio 1983 (red. P.-R. Tragan) (Studia Anselmiana 90. Sacramentum 8; Roma: Pontificio Ateneo S. Anselmo 1985) 47-120.

108 J.F. Moloney, „When is John Talking about Sacraments?”, ABR 30 (1982) 10.

109 Zob. także T.K. Seim, „Baptismal Reflections in the Fourth Gospel”, Ablution, Initiation, and Baptism. Late Antiquity, Early Judaism, and Early Christianity (red. D. Hellholm - T. Vegge - Ø. Norderval) (BZNW 176; Berlin - Boston, MA: De Gruyter 2011) 717-734.

110 Moloney, „When is John Talking about Sacraments?”, 10-33. Trzecie kryterium odwołuje się do interpretacji niektórych Janowych tekstów jako wymierzonych przeciw doktrynie doketyzmu. 
J.F. Moloney zwraca również uwagę na wykonawcę czynności umycia nóg. Co zdumiewające, jest nim Jezus. Czwarta Ewangelia jest rzeczywiście jedyną Ewangelią kanoniczną, która mówi o Jezusie udzielającym chrztu $(4,1)$. Ewangelista dodaje jednak szybko sprostowanie, iż chrztu udzielali uczniowie Jezusa, a nie On sam $(4,2)$. Skoro zatem Jezus nie jest szafarzem sakramentu chrztu w narracji Janowej, nie należy przypisywać znaczenia chrzcielnego do Jezusowego gestu umycia nóg.

\section{Podsumowanie}

Z pewnością powyższe argumenty wskazują na atrakcyjność interpretacji, w świetle której stan oczyszczenia uczniów, wyrażony przez ó $\lambda \varepsilon \lambda o v \mu \varepsilon ́ v o \varsigma(13,10)$, winien być rozumiany jako stan uzyskiwany poprzez chrzest. Mniej przekonujące jest natomiast rozumienie samego gestu umycia nóg opisywanego przez ví $\pi \tau \omega$ jako odwołania do sakramentu chrztu. Ścisłe powiązanie ogólnego oczyszczenia $\mathrm{z}$ chrztem wyklucza rozumienie samego umycia nóg jako odniesionego do chrztu. O wiele bardziej przekonujące jest przyjęcie istnienia ogólnego odniesienia obu obmyć z 13,10, jako symbolu chrztu, do skutków odkupieńczej śmierci Jezusa. Przyjęcie tej ogólnej interpretacji nie wyjaśnia jednak wszystkich detali tekstu 13,1-20, w tym rozróżnienia dwóch obmyć w 13,10. W efekcie racjonalnym jest przyjęcie konkluzji, w której symbolizm chrzcielny winien być widziany jednie jako ogólne tło czy też drugoplanowy sens narracji.

\subsection{Eucharystia}

W Janowym opisie Ostatniej Wieczerzy nie ma wątków eucharystycznych, obecnych w relacjach synoptycznych. Z tego względu niektórzy komentatorzy zasugerowali, że ewangelista zastąpił ustanowienie Eucharystii z 1 Kor oraz Ewangelii synoptycznych opisem umycia nóg ${ }^{111}$. Oto argumenty przemawiające za

Praktycznie każdy z antydoketycznych tekstów może zostać odniesiony do Eucharystii czy chrztu. Zdaniem J.F. Moloneya teksty są nie tyle antydoketyczne, ile wyrażają wspólnotowy charakter Kościoła, w którym kluczową rolę odgrywał chrzest i Eucharystia. Czwarte kryterium odnosi się do problemu fizycznej nieobecności Jezusa, z którym borykała się Wspólnota Janowa. Sakramenty, a konkretnie chrzest i Eucharystia, były rozumiane przez Wspólnotę Janową jako sposoby obecności Jezusa. Użycie tych dwóch kryteriów w przypadku J 13,1-20 nie wydaje się specjalnie owocne.

111 Do autorów opowiadających się za interpretacją eucharystyczną, którą z zasady łączą z interpretacją chrzcielną, należą: A. Loisy, Le quatrième évangile (Paris: Alphonse Picard et Fils 1903) 709-716; Bauer, Das Johannesevangelium, 171-173; M. Goguel, Jésus (Biblothèque Historique; Paris: Payot ${ }^{2}$ 1950) 359; H. Strathmann, Das Evangelium nach Johannes (NTD 4; Göttingen: Vandenhoeck \& Ruprecht $\left.{ }^{8} 1955\right)$ 198-199; A.J.B. Higgins, The Lord's Supper in the 
taką sugestią. (1) Zarówno w opisach ustanowienia Eucharystii, jak i w Janowym opisie obmycia nóg występuje nakaz powtarzania tychże aktów (1 Kor 11,24; Łk 22,19; J 13,14-15.17). (2) Jeśli ryt obmycia nóg podkreślał wspólnotowość (solidarność ze wspólnotą) i potwierdzał przynależność do wspólnoty, w taki sam sposób funkcjonowała Eucharystia: była znakiem solidarności i potwierdzenia przynależności do wspólnoty ${ }^{112}$. (3) Nadto, skoro Jan czyni aluzje do Eucharystii w opisach konkretnych wydarzeń z życia Jezusa (np. cud w Kanie oraz cud rozmnożenia chleba i ryb wraz z mową o chlebie życia), można zatem domniemywać obecność aluzji do Eucharystii również w konkretnym wydarzeniu, jakim było obmycie nóg. (4) Egzegeci wskazali także na redakcyjne łączniki pomiędzy J 13 a J $6^{113}$. (5) Dla wielu wzmianka o $\psi \omega \mu$ íov („kawałek chleba") w bezpośrednim kontekście $(13,26.27 .30)$ jest również odniesieniem do Eucharystii ${ }^{114}$. (6) Z pewnością gest umycia nóg wyraża najgłębsze przesłanie zawarte w Eucharystii. Otóż wspólnocie zbierającej się na Eucharystii winien towarzyszyć ten sam duch i postawa, które charakteryzowały Jezusa w czasie Jego męki i śmierci, a zatem miłość i gotowość służby. Taką właśnie charakterystykę Eucharystii przedstawia Paweł wspólnocie w Koryncie (1 Kor $11,17-34)^{115}$. (7) Synoptyczny opis ustanowienia Eucharystii oraz Janowy opis umycia nóg są analogiczne w swej funkcji, jaką pełnią w kontekście narracji o Ostatniej Wieczerzy. Oba opisy są ,profetycznymi gestami objawiającymi prawdziwe znaczenie śmierci Jezusa", z zachowaniem specyficznej teologicznej perspektywy każdego z ewangelistów ${ }^{116}$. (8) Kontekstem umycia nóg jest

New Testament (Studies in Biblical Theology 6; London: SCM 1952) 84-85; G.H.C. MacGregor, „The Eucharist in the Fourth Gospel”, NTS 9 (1963) 112-114; Cullmann, La foi et le culte de l'Église primitive, 199; J.N. Suggit, „John 13.1-30: The Mystery of the Incarnation and of the Eucharist", Neotestamentica 19 (1985) 64-70. W. Lohse (Die Fusswaschung, 120-121) uważa, że interpretacja eucharystyczna wydaje się naturalnie narzucającą się oryginalnym czytelnikom czwartej Ewangelii.

112 Zdaniem Cullmanna (La foi et le culte de l'Église primitive, 199) obecność symboliki sakramentalnej w tym tekście miałaby odwoływać się do dwóch zasad: (1) tekst ten ma wskazać jedność sakramentu chrztu i Eucharystii oraz jednocześnie (2) ukazać różnicę między tymi dwoma sakramentami. Tak jak chrzest udzielony jest tylko raz (śmierć Jezusa nie może być powtórzona), tak Eucharystia (sakrament miłości wspólnoty) ma być powtarzana. Chrzest dotyka indywidualnej osoby, podczas gdy Eucharystia jest sakramentem wspólnotowym.

113 R.H. Lightfood, St. John's Gospel. A Commentary (Oxford: Oxford University Press 1956) 274; Richter, „Die Fusswaschung”, 22.

114 J.F. Moloney, „The Structure and Message of John 13:1-38”, ABR 34 (1986) 11: „clearly Eucharistic”. Rozległą argumentację za eucharystycznym rozumieniem J 13,21-39 przedstawia J.F. Moloney w innym swym artykule: „A Sacramental Reading of John 13:1-38”, CBQ 53 (1991) 237-256. Moloney (ibidem, 256) konkluduje: „Eucharist is not the main feature of John 13. Like the baptismal hint in vv 1-17, the eucharistic practice of the community forms the background, not the foreground to the narrative of vv 21-38". Zob. także X. Léon-Dufour, Sharing the Eucharistic Bread. The Witness of the New Testament (Mahwah, NJ: Paulist Press 1987) 82-95.

115 Beutler, Giovanni, 422.

116 Schneiders, „The Foot Washing”, 81, przyp. 22. 
uczta $(\delta \varepsilon i \pi \pi v o v-13,2)$. (9) Interpretacja eucharystyczna gestu umycia nóg nie wszystkich przekonuje z racji braku w tekście Janowym wzmianki o winie i jego piciu. Z drugiej jednak strony ewangelista wprost mówi o chlebie i jego jedzeniu

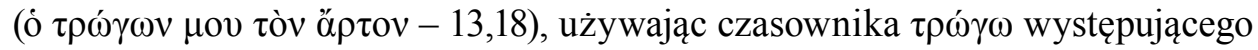
w eucharystycznej mowie Jezusa w 6,54.56.57.58.

Na niekorzyść interpretacji eucharystycznej przemawia fakt jej nieznajomości w starożytności ${ }^{117}$. Jednymi z najwcześniejszych zwolenników symbolizmu eucharystycznego są bowiem dopiero średniowieczni autorzy Rupert z Deutz (zm. 1130) ${ }^{118}$ oraz Hugo od św. Wiktora (zm. 1141).

\subsection{Kapłaństwo}

H. Sahlin w kluczu interpretacji typologicznej odwołał się do obmyć kapłańskich dokonywanych przed sprawowaniem kultu (zob. Wj 40,30-31). Jezusowy gest umycia nóg byłby zatem obmyciem przygotowującym uczniów do wykonywania w przyszłości czynności kultycznych, a więc kapłańskich ${ }^{119}$.

Umycie nóg to akt wyjątkowy i jednorazowy. E. Lohmeyer podkreśla, iż takim aktem Jezus ustanowił kapłanów swej eschatologicznej wspólnoty. Fakt, iż ryt ten nastąpił w kontekście Ostatniej Wieczerzy, ma podkreślać przeznaczenie uczniów-kapłanów do sprawowania Eucharystii ${ }^{120}$.

\subsection{Nowy (nieznany) sakrament}

Pomysł widzenia tutaj nowego, sui generis, współcześnie nieznanego sakramentu postulował już Nikolaus Ludwig von Zinzendorf (1700-1760). W geście umycia nóg widzi się zatem ryt znany i praktykowany jedynie we Wspólnocie Janowej, w której nabrał on wręcz znaczenia sakramentalnego ${ }^{121}$. Dla przykładu R.B. Edwards sugeruje, iż umycie nóg winno być interpretowane jako sakrament identyfikacji z Jezusem $w$ jego pokornej służbie i śmierci ${ }^{122}$. B.W. Bacon zwrócił

117 Krytyka wysunięta przez R.E. Browna (John, II, 559).

118 Rupert z Deutz, Commentarium in Joannem 11 (PL 169,679).

119 H. Sahlin, Zur Typologie des Johannesevangeliums (UUÅ 1950/4; Uppsala - Leipzig: Lundequistska 1950) 51-52.

120 E. Lohmeyer, „Die Fusswaschung”, ZNW 38 (1939) 74-94. W tym samym duchu D.H. Tripp, „Meanings of the Foot-Washing: John 13 and Oxyrhynchus Papyrus 840”, ExpT 103/8 (1992) 237-239.

121 Zob. M.F. Connell, „Nisi Pedes. Except for the Feet. Footwashing in the Community of John's Gospel”, Worship 7 (1996) 517-531; Thomas, Footwashing, passim.

122 Edwards, „The Christological Basis of the Johannine Footwashing”, 378-379. 
uwagę, iż chronologia Janowa umieszcza ryt umycia nóg przed Paschą. Fakt ten pozwala widzieć gest umycia nóg jako ryt przygotowania do zbliżającej się Paschy. Gest Jezusa miałby odpowiadać rytowi Kiddusz (,poświęcenie”), w którym wypowiadano błogosławieństwo nad kielichem wina w momencie rozpoczynania szabatu lub większego święta, w tym Paschy. Ten sakramentalny ryt, praktykowany w Kościele Efeskim (czyli Janowym), miałby oczyszczać z grzechów popełnionych po chrzcie i przygotowywać do Eucharystii ${ }^{123}$. Faktem jest, iż pierwotne chrześcijaństwo znało i praktykowało umywanie nóg ${ }^{124}$. W przytłaczającej jednak większości praktykowany gest umycia nóg rozumiano w starożytności niesakramentalnie, jako znak gościnności oraz uniżenia i służby na wzór Chrystusa. Faktem jest również, iż od IV w. znak ten w niektórych kościołach zachodnich łączono z sakramentem chrztu ${ }^{125}$. Współcześnie, prócz liturgii Wielkiego Czwartku, obmycie nóg praktykowane jest w niektórych wspólnotach pentakostalnych i baptystycznych ${ }^{126}$.

\section{Bibliografia}

à Lapide, C., Commentaria in Scripturam Sacram. XVI. In SS. Lucam et Joannem (Paris: Ludovicus Vivès 1867).

Bacon, B.W., „The Sacrament of Footwashing”, Expository Times $43 / 5$ (1932) 218-221.

Barrett, C.K., The Gospel according to St John. An Introduction with Commentary and Notes on the Greek Text (London: SPCK ${ }^{2} 1978$ ).

Bauckham, R., „Did Jesus Wash His Disciples' Feet?”, Authenticating the Activities of Jesus (red. B.D. Chilton - C.A. Evans) (New Testament Tools and Studies 28/2; Leiden - Boston - Köln: Brill 1999) 411-429.

123 B.W. Bacon, „The Sacrament of Footwashing”, ExpT 43/5 (1932) 218-221.

124 Najstarszym przykładem jest 1 Tm 5,9-10, a następnie Tertulian, De corona 8; tenże, Ad uxorem 2,4; Kanony Atanazego 66 (biskup ma obmywać nogi swoim kapłanom); Orygenes, Hom. in Gen. 4,2; Jan Chryzostom, Hom. in Jo. 71; tenże, Hom. in Gen. 46; Synod w Elwirze (kanon 48); Ambroży, De Spiritu Sancto 1,15; tenże, De Myst. 3,4-5; Augustyn, In Jo. 58,4; tenże, Epist. 55,33; Konstytucje Apostolskie 3,19; Jan Kasjan, De institutis coenobiorum, 4,19; Pachomiusz, Regula ad monachos, 51-52; Cezary z Arles, Sermo 60; 86; 104 oraz 202; Sozomen, Eccl. Hist. 1,11,10; Benedykt z Nursji, Regula Monachorum 35 oraz 53. Jest wielce prawdopodobne, że wyrażenie „dotykać jego skóry” w Męczeństwie Polikarpa 13,2 odnosi się do mycia nóg, podobnie jak „ręczne obmycia” w dziele Tertuliana Apologia, 39. Dokładne omówienie tych tekstów w Thomas, Footwashing, 129-146.

125 Np. Ambroży, De Myst. 3,5.7; Synod w Elwirze (kanon 48). Więcej zob. Beatrice, La lavanda dei piedi; Bauckham, „Did Jesus Wash His Disciples’ Feet?”, 425-429; Egasse, Le lavement des pieds.

126 Zob. F.D. Macchia, „Is Footwashing the Neglected Sacrament? A Theological Response to John Christopher Thomas", PNEUMA. The Journal of the Society for Pentecostal Studies 19/2 (1997) 239-249. O konieczności dosłownego wdrażania w życie przykładu Jezusa zob. A. Edgington, „Footwashing as an Ordinance,” Grace Theological Journal 6 (1985) 425-434. 
Bauer, W., Das Johannesevangelium erklärt (Handbuch zum Neuen Testament 6; Tübingen: Mohr Siebeck 1912. ${ }^{3} 1933$ ).

Beatrice, P.F., La lavanda dei piedi. Contributo alla storia della antiche liturgie cristiane (Bibliotheca Ephemerides Liturgicae Subsidia 28; Roma: C.L.V. Edizioni litrugiche 1983).

Bennema, C., „Mimesis in John 13: Cloning or Creative Articulation?”, Novum Testamentum 56 (2014) 261-274.

Bernard, J.H., A Critical and Exegetical Commentary on the Gospel According to St. John (International Critical Commentary; Edinburgh: T\&T Clark 1928).

Beutler, J., Das Johannesevangelium. Kommentar (Freiburg - Basel - Wien: Herder 2013).

Bovon, F., „Fragment Oxyrhynchus 840, Fragment of a Lost Gospel, Witness of an Early Christian Controversy Over Purity", Journal of Biblical Literature 119 (2000) 705-728.

Braun, F.-M., „Le levement des pieds et la réponse de Jésus à saint Pierre”, Revue Biblique 44 (1935) 22-33.

Brown, R.E., recenzja G. Richter, Die Fusswaschung im Johannesevangelium. Geschichte ihrer Deutung, Theological Studies 30 (1969) 120-122.

Brown, R.E., The Gospel of John. Introduction, Translation and Notes (Anchor Bible 29A; Garden City, NY: Doubleday 1970).

Brown, R.E., An Introduction to the Gospel of John. Edited, Updated, Introduced, and Concluded by Francis J. Moloney (The Anchor Bible Reference Library; New York, NY et al.: Doubleday 2003).

Bultmann, R., Das Evangelium des Johannes (Kritisch-exegetischer Kommentar über das Neue Testament; Göttingen: Vandenhoeck \& Ruprecht $\left.{ }^{10} 1968\right)$.

Carson, D.A., The Gospel according to John (Pillar New Testament Commentary; Leicester, U.K.: Apollos/Grand Rapids, MI - Cambridge, U.K.: Eerdmans 1991).

Clark-Soles, J., „John 13: Of Footwashing and History”, John, Jesus, and History. Volume 2: Aspects of Historicity in the Fourth Gospel (red. P.N. Anderson - F. Just - T. Thatcher) (Early Christianity and Its Literature 2; Atlanta, GA: Society of Biblical Literature 2009) 255-269.

Coloe, M.L., „Welcome into the Household of God: The Foot Washing in John 13”, Catholic Biblical Quarterly 66 (2004) 400-415.

Connell, M.F., „Nisi Pedes. Except for the Feet. Footwashing in the Community of John's Gospel”, Worship 7 (1996) 517-531.

Cullmann, O., La foi et le culte de l'Église primitive (Bibliothèque Théologique; Neuchatel: Delachaux et Niestlé 1963).

Cullmann, O., The Johannine Circle. Its Place in Judaism, among the Disciple of Jesus and in Early Christianity. A Study in the Origin of the Gospel of John (London: Westminster 1976).

Culpepper, R.A., „The Johannine Hypodeigma: A Reading of John 13”, Semeia 53 (1991) 133-151.

Culpepper, R.A., The Johannine School. An Evaluation of the Johannine-School Hypothesis Based on an Investigation of the Nature of Ancient Schools (SBL Dissertation Series 26; Missoula, MO: Scholars Press 1975).

D’Agostino, M., „«Si alzò da tavola, depose le vesti» Una trasfigurazione in Gv 13,1-15?”, Il quarto Vangelo (red. C. Doglio) (Parole di Vita 6; Padova: Edizioni Messaggero 2015) 200-206.

Derrett, J.D.M., „The Footwashing in John 13 and the Alienation of Judas Iscariot”, Revue Internationale des Droits de l'antiquité 24 (1977) 3-19.

Destro, A. - Pesce, M., „L'iniziazione dei discepoli nel Vangelo di Giovanni: La lavanda dei piedi come rito di ingresso al discepolato", Seiano di Vico Equense (NA). 21 agosto - 5 settembre 1997 (B.E.L. Subsidia 99; Roma: C.L.V.-Edizioni liturgiche 1998) 47-74. 
Destro, A. - Pesce, M., „La lavanda dei piedi di Gv 13,1-20, il Romanzo di Esopo e i Saturnalia di Macrobio", Biblica 80/2 (1999) 240-249.

Destro, A. - Pesce, M., „La lavanda dei piedi nel Vangelo di Giovanni: un rito di inversione”, Atti del VI Simposio di Efeso su S. Giovanni apostolo (red. L. Padovese) (Turchia: La Chiesa e la Sua Storia 11; Roma: Istituto francescano di spiritualità - Pontificio Ateneo Antoniano 1996) 9-27.

Dodd, C.H., Historical Tradition in the Fourth Gospel (Cambridge: Cambridge University Press 1965).

Dodd, C.H., The Interpretation of the Fourth Gospel (Cambridge: Cambridge University Press 1953).

Dunn, J.D.G., „The Washing of the Disciples' Feet in John 13,1-20”, Zeitschrift für die Neutestamentliche Wissenschaft und die Kunde der älteren Kirche 61 (1970) 247-252.

Durand, G., L'imagination symbolique (Paris: Presses Universitaires de France 1964).

Echle, H.A., „The Baptism of the Apostles. A Fragment of Clement of Alexandria's Lost Work

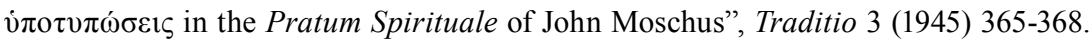

Edgington, A., „Footwashing as an Ordinance”, Grace Theological Journal 6 (1985) 425-434.

Edwards, R.B., „The Christological Basis of the Johannine Footwashing”, Jesus of Nazareth: Lord and Christ. Essays on the Historical Jesus and New Testament Christology (red. J.B. Green - M. Turner) (Grand Rapids, MI: Eerdmans 1994) 367-383.

Egasse, C., Le lavement des pieds. Recherche sur une pratique négligée (Christianismes Antiques; Genève: Labor et Fides 2015).

Eisler, R., „Zur Fusswaschung am Tage vor dem Pessah (Ev. Joh. 13,2-16)”, Zeitschrift für die Neutestamentliche Wissenschaft und die Kunde der Älteren Kirche 14 (1913) 268-271.

Fiebig, P., „Die Fusswaschung”, Angelos 3 (1930) 126-128.

Fridrichsen, A., „Bemerkungen zur Fusswaschung Joh 13”, Zeitschrift für die Neutestamentliche Wissenschaft und die Kunde der Älteren Kirche 38 (1939) 94-96.

Gardner, J.F. - Wiedemann T., The Roman Household. A Sourcebook (London: Routledge 1991).

Gibson, D., „The Johannine Footwashing and the Death of Jesus: A Dialogue with Scholarship”, The Scottish Bulletin of Theology 25/1 (2007) 50-60.

Giurisato, G., „John 13:10: An Archaeological Solution of Textcritical Problem”, Liber Annuus 58 (2008) 73-80.

Goguel, M., Jésus (Biblothèque Historique; Paris: Payot ${ }^{2} 1950$ ).

Grelot, P., „L'interprétation pénitentielle du lavement des pieds: examen critique”, L'homme devant Dieu. Mélanges offerts au Père Henri de Lubac. Exégèse et patristique (Théologie 56; Paris: Aubier 1963) 75-91.

Haring, N.M., „Historical Notes on the Interpretation of John 13:10”, Catholic Biblical Quarterly 13 (1951) 355-380.

Higgins, A.J.B., The Lord's Supper in the New Testament (Studies in Biblical Theology 6; London: SCM 1952).

Hoskyns, E., The Fourth Gospel (red. F.N. Davey) (London: Faber \& Faber 1947).

Hultgren, A.J., „The Johannine Footwashing (13.1-11) as Symbol of Eschatological Hospitality”, New Testament Studies 28 (1982) 539-546.

Jeremias, J., „Der Zusammenstoß Jesus mit dem pharisäischen Oberpriester auf dem Tempelplatz: Zu Pap. Ox. V, 840", Coniectanea Neotestamentica 11 (1947) 97-108.

Jeremias, J., Die Abendmahlsworte Jesu (Göttingen: Vandenhoeck \& Ruprecht $\left.{ }^{3} 1960\right)$.

Kadeparambil, A., Origen and Augustine on John 13. Anagogical And/Or Literal? An Exegetical and Theological Comparison (Bangalore: Asian Trading Corporation 2011).

Kanagaraj, J.J., „Johannine Jesus, the Supreme Example of Leadership: An Inquiry into John 13:1-20", Themelios 29/3 (2004) 15-26. 
Kempiak, R., „«Poznacie prawdę, a prawda was wyzwoli» (J 8,32). Wyzwolenie - wolność w ujęciu Janowym", Scriptura Sacra 10 (2006) 187-214.

Kieffer, R., „L'arrière-fond juif du lavement des pieds”, Revue Biblique 105 (1998) 546-555.

Kötting, B. - Halama, D., „Fusswaschung”, Reallexikon für Antike und Christentum. Sachwörterbuch zur Auseinandersetzung des Christentums mit der antiken Welt (red. T. Klauser) (Stuttgart: Hiersemann 1972) VIII, 743-777.

Kruger, M.J., The Gospel of Savior. An Analysis of P.Oxy V 840 and Its Place in the Gospel Traditions of Early Christianity (Texts and Editions for New Testament Study 1; Leiden: Brill 2005).

Kubiś, A., „Poznacie prawdę i prawda was wyzwoli. Związek między Janowymi koncepcjami prawdy i wolności w świetle J 8,31-36”, Prawda was wyzwoli (Scripturae Lumen. Biblia i Jej Oddziaływanie 4; Tarnów: Biblos 2012) 59-85.

Kubiś, A., „Radość Przyjaciela Oblubieńca z powodu głosu Oblubieńca w J 3,29”, Radość Ewangelii. Biblijne źródła chrześcijańskiej radości (red. A. Zawadzki) (Analecta Biblica Lublinensia 13; Lublin: Wydawnictwo KUL 2016) 163-192.

Kysar, R., The Fourth Evangelist and His Gospel. The Examination of Contemporary Scholarship (Minneapolis, MN: Fortress 1975).

la Potterie, I. de, „«To be Born Again of Water and the Spirit» - The Baptismal Text of John 3,5”, The Christian Lives by the Spirit (Staten Island, N.Y.: Alba House1971) 1-36.

Lalande, A., „Symbole: sens”, Vocabulaire Critique et Technique de la Philosphie (Paris: Alcan 1926).

Léon-Dufour, X., Sharing the Eucharistic Bread. The Witness of the New Testament (Mahwah, NJ: Paulist Press 1987).

Lightfood, R.H., St. John's Gospel. A Commentary (Oxford: Oxford University Press 1956).

Lohmeyer, E., „Die Fusswaschung”, Zeitschrift für die Neutestamentliche Wissenschaft und die Kunde der Älteren Kirche 38 (1939) 74-94.

Lohse, W., Die Fusswaschung (Joh 13.1-20). Eine Geschichte ihrer Deutung (dysertacja doktorska; Friedrich-Alexander-Universität zu Erlangen-Nürnberg 1967).

Loisy, A., Le quatrième évangile (Paris: Alphonse Picard et Fils 1903).

Macchia, F.D., „Is Footwashing the Neglected Sacrament? A Theological Response to John Christopher Thomas", PNEUMA. The Journal of the Society for Pentecostal Studies 19/2 (1997) 239-249.

MacEvilly, J., An Exposition of the Gospel of St. John (Dublin - New York, NY: Benziger Brothers 1889. ${ }^{2}$ 1902).

MacGregor, G.H.C., „The Eucharist in the Fourth Gospel”, New Testament Studies 9 (1963) 112-114.

Maldonatus, J., Commentarii in quatuor evangelistas (Moguntiae: Brickman 1651).

Malina, B.J., „The Received View and What It Cannot Do: III John and Hospitality”, Semeia 35 (1986) 171-189.

Manns, F., „Le lavement des pieds: essai sur la structure et la signification de Jean 13”, Revue des Sciences Religieuses 55 (1981) 164-166.

Massyngbaerde Ford, J., Redeemer - Friend and Mother. Salvation in Antiquity and in the Gospel of John (Minneapolis, MN: Fortress 1997).

Mathew, B., The Johannine Footwashing as the Sing of Perfect Love. An Exegetical Study of John 13:1-20 (Wissenschaftliche Untersuchungen zum Neuen Testament 2/464; Tübingen: Mohr Siebeck 2018).

Matson, M.A., „To Serve as Slave. Footwashing as Paradigmatic Status Reversal”, One in Christ Jesus. Essays on Early Christianity and „All That Jazz”, in Honor of S. Scott Bartchy (red. D.L. Matson - K.C. Richardson) (Eugene, OR: Pickwick Publications 2014) 113-131. 
Mędala, S., Ewangelia wedtug świętego Jana. Rozdziaty 13-21. Wstęp, przekład z oryginału, komentarz (Nowy Komentarz Biblijny. Nowy Testament 4/2; Częstochowa: Edycja Świętego Pawła 2010).

Michl, J., „Der Sinn der Fusswaschung”, Biblica 40 (1959) 697-708.

Moloney, J.F., „A Sacramental Reading of John 13:1-38”, Catholic Biblical Quarterly 53 (1991) 237-256.

Moloney, J.F., „The Structure and Message of John 13:1-38”, Australian Biblical Review 34 (1986) $1-16$.

Moloney, J.F., „When is John Talking about Sacraments?”, Australian Biblical Review 30 (1982) $10-33$.

Moloney, F.J., The Gospel of John (Sacra Pagina 4; Collegeville, MI: The Liturgical Press 1998). Neyrey, J.H., The Gospel of John (The New Cambridge Bible Commentary; Cambridge: Cambridge University Press 2007).

Niemand, C., Die Fusswaschungserzählung des Johannesevangeliums. Untersuchungen zu ihrer Entstehung und Überlieferung im Urchristentum (Studia Anselmiana 114; Roma: Pontificio Ateneo S. Anselmo 1993).

O’Neil, J.C., „John 13:10 Again”, Revue Biblique 101 (1994) 67-74.

Odeberg, H., The Fourth Gospel. Interpreted in Relation to Contemporaneous Religious Currents in Palestine and the Hellenistic-Oriental World (Uppsala - Stockholm: Almqvist \& Wiksells Boktryckeri 1929).

Olsson, B., „The Meanings of John 13,10: A Question of Genre?”, Studies in the Gospel of John and its Christology. Festschrift Gilbert Van Belle (red. J. Verheyden - G. van Oyen - M. Labahn) (Bibliotheca Ephemeridum Theologicarum Lovaniensium 265; Leuven - Paris - Walpole, MA: Peeters 2014) 317-325.

Olsson, B., Structure and Meaning in the Fourth Gospel. A Text-Linguistic Analysis of John 2:1-11 and 4,1-42 (Coniectanea Biblica. New Testament Series 6; Lund: Gleerup 1974).

Orygenes, Komentarz do Ewangelii według św. Jana (tłum. S. Kalinkowski) (Źródła Myśli Teologicznej 27; Kraków: WAM 2003).

Peloni, A., „The Daily Washing of the Once Bathed (St. John xiii. 10)”, The Expositor 2/4 (1882) 146-156.

Pesce, M., „Il lavaggio dei piedi (Gv 13,1-20)”, Opera giovannea (red. G. Ghiberti) (Logos. Corso di Studi Biblici 7; Torino: Elledici 2002) 233-250.

Riceour, P., The Conflict of Interpretations. Essays in Hermeneutics (red. D. Ihde) (Studies in Phenomenology and Existential Philosophy; Evanston, IL: Northwestern University Press 1974).

Richter, G., „Die Fusswaschung Joh 13,1-20”, Münchener Theologische Zeitschrift 16 (1965) 13-26 = Richter G., „Die Fusswaschung Joh 13,1-20”, Studien zum Johannesevangelium (red. J. Hainz) (Biblische Untersuchungen 13; Regensburg: Pustet 1977) 42-57.

Richter, G., Die Fusswaschung im Johannesevangelium. Gesichte ihrer Deutung (Biblische Untersuchungen 1; Regensburg: Pustet 1967).

Robinson, J.A.T., „The Significance of the Foot-Washing”, Neotestamentica et Patristica. Freundengabe Oscar Cullmann (red. W.C. van Unnik) (Novum Testamentum Supplements 6; Leiden: Brill 1962) 144-147.

Rusconi, C., Le nozze dell'Agnello. La metafora delle nozze in San Giovanni (Scienze Religiose Gregorio da Rimini; Rimini: Pazzini 2008).

Sahlin, H., Zur Typologie des Johannesevangeliums (Uppsala Universitets Årsskrift 1950/4; Uppsala-Leipzig: Lundequistska 1950). 
Sammer, J., „Why Did Jesus Wash His Disciples Feet?”, Aeon. A Journal of Myth and Science 3/4 (1993) 21-32.

Sanders, J.N., A Commentary on the Gospel of St. John (red. B.A. Mastin) (London: Adam \& Charles Black 1968).

Schneiders, S.M., „The Foot Washing (John 13:1-20): An Experiment in Hermeneutics”, Catholic Biblical Quarterly 43 (1981) 76-92.

Schwank, B., „Exemplum dedi vobis. Die Fusswaschung (13,1-17)”, Sein und Sendung 28 (1963) 4-17.

Seim, T.K., „Baptismal Reflections in the Fourth Gospel”, Ablution, Initiation, and Baptism. Late Antiquity, Early Judaism, and Early Christianity (red. D. Hellholm - T. Vegge - Ø. Norderval) (BZNW 176; Berlin - Boston, MA: Walter de Gruyter 2011) 717-734.

Spitta, F., Das Johannes-Evangelium als Quelle der Geschichte Jesu (Göttingen: Vandenhoeck \& Ruprecht 1910).

Stibbe, M.W.G., John as Storyteller. Narrative Criticism and the Fourth Gospel (Society for New Testament Studies Monograph Series 73; Cambridge: Cambridge University Press 1992).

Strathmann, H., Das Evangelium nach Johannes (Das Neue Testament Deutsch 4; Göttingen: Vandenhoeck \& Ruprecht $\left.{ }^{8} 1955\right)$.

Suggit, J.N., ,John 13.1-30: The Mystery of the Incarnation and of the Eucharist”, Neotestamentica 19 (1985) 64-70.

Swetnam, J., recenzja G. Richter, Die Fusswaschung im Johannesevangelium. Geschichte ihrer Deutung, Biblica 49/3 (1968) 439-444.

Święty Tomasz z Akwinu, Komentarz do Ewangelii Jana (tłum. T. Bartoś) (Biblioteka Europejska; Kęty: Wydawnictwo Marek Derewiecki 2018).

Thomas, J.C., „A Note on the Text of John 13:10”, Novum Testamentum 291 (1987) 46-52.

Thomas, J.C., Footwashing in John 13 and the Johannine Community (Journal for the Study of the New Testament Supplement Series 61; Sheffield: JSOT Press 1991).

Thompson, M.M., „«His Own Received Him Not»: Jesus Washes the Feet of His Disciples”, The Art of Reading Scripture (red. E.F. Davis) (Grand Rapids, MI: Eerdmans 2003) 258-273.

Tragan, P.-R., „Battesimo e fede cristologica nel dialogo tra Gesù e Nicodemo (Gv 3,1-21)”, Fede e sacramenti negli scritti giovannei. Atti del VI convegno di teologia sacramentaria. Roma, 23-25 maggio 1983 (red. P.-R. Tragan) (Studia Anselmiana 90. Sacramentum 8; Roma: Pontificio Ateneo S. Anselmo 1985) 47-120.

Tripp, D.H., „Meanings of the Foot-Washing: John 13 and Oxyrhynchus Papyrus 840”, Expository Times 103/8 (1992) 237-239.

Versnel, H.S., „Saturnus and the Saturnalia”, Inconsistencies in Greek and Roman Religion. II. Transition and Reversal in Myth and Ritual (Studies in Greek and Roman Religion 6; Leiden: Brill 1993) 136-227.

von Campenhausen, H., „Zur Auslegung von Joh 13,6-10”, Zeitschrift für die Neutestamentliche Wissenschaft und die Kunde der Älteren Kirche 33 (1934) 259-271.

von Wahlde, H.U., The Gospel and Letters of John. I. Introduction, Analysis, and Reference (Eerdmans Critical Commentary; Grand Rapids, MI - Cambridge, U.K.: Eerdmans 2010).

Weiss, H., „Foot Washing in the Johannine Community”, Novum Testamentum 21 (1979) 298-325.

Wettstein (Wetstenius), J.J., Novum Testamentum graecum editionis receptae cum lectionibus variantibus codicum mss. editionum aliarum, versionum et patrum necnon commentario pleniore ex scriptoribus veteribus hebraeis, graecis et latinis (Amstelaedami: Ex officina Dommeriana 1751).

Zumstein, J., „Die johanneische Auffassung der Macht gezeigt am Beispiel der Fusswaschung (Joh 13,1-17)", Recht-Macht - Gerechtigkeit (red. J. Mülhausen) (Gütersloh: Kaiser 1988) 370-385. 
Zumstein, J., „Le lavement des piedes (Jean 13,1-20): un exemple de la conception johannique du pouvoir", Revue de Théologie et de Philosophie 132 (2000) 345-360.

Zumstein J., „Le porcessus johannique de la relecture à l'exemple de Jean 13,1-20”, Regards croisés sur la Bible. Études sur le point de vue. Actes du III colleque international du Réseau de recherche en narrativité biblique. Paris, 8-10 juin 2006 (red. D. Marguerat) (Lectio Divina; Paris: Cerf 2007) 325-338.

Zumstein J., L'évangile selon saint Jean (13-21) (Commentaire du Nouveau Testament. Duxième série 4b; Genève: Labor et Fides 2007). 